\title{
The thecamoebae (Protozoa, Rhizopoda) of small Amazonian forest streams and their possible use as indicator organisms for waterquality (1)
}

\author{
Ilse Walker [ ${ }^{2}$ )
}

\begin{abstract}
The thecaboemae fauna of seven central amazonian forest streams - among them the stream of the "Bacia Modelo" - was analised. 129 morphotypes are shortly characterized in a "list of morphotypes" with accompanying figures (Plates 1-7); 39 morphotypes were observed alive and food uptake determined in 20 of these. Their food consists primarily of spores and hyphae of fungi which decompose submerged leaf litter and detritus. Analysis of sequential samples suggests that most species were found in each stream, but that collection in further streams is expected to increase the total number of morphotypes considerably. Frequency and distribution of morphotypes, as well as tota! population density, are characteristic for each stream and seem to reflect water quality and geographic distance between streams. Thecamoebae density is $2-5$ times higher in original, un-mixed black water than in crystalline water of similarly low conductivity. Total number of morphotypes is almost invariable between streams $(64-76)$. These results suggest that thecamoebae populations as a whole, and single species in particular, may be suitable indicators for the quality of waters in natural and in distrurbed streams.
\end{abstract}

\section{INTRODUCTION}

This study is not an attempt at thecamoebae systematics - this should be emphasized right at the start - rather, it is the adventure an unsuspecting biologist blunders into when taking a first look at the fauna of Amazonian "Terra Firme" streams. The density and variety of thecamoebae in the substratum of organic detritus is so staggering that one wants to know more about it, and one begins to wonder whether this phenomenon might not sarve a useful purpose. What are these cells living off in these almost distilled waters? What is their role in the food web of the general stream fauna? Are species and/or their frequencies characteristic for particular streams and for the quality of their waters? Could the distance of geographic separation between river systems with their thecamoebae spectra tell us something about the process of evolution and speciation?

The analysis presented in this study concentrates on the question whether the spectrum of species distribution and frequency could serve as indicator for water quality, specifically also with the aim to compare, in future, the streams of INPA's experimental basins, the "Bacia Modelo" (Bacia I) in its primary, undisturbed condition, and the "Bacia do Manejo" (Bacia III) before and during management. Observations on food ingestion are reported and throw some light on the possible ecological role of these thecamebians in their habitat. Evolutionary aspects are barely hinted at, discussion of these problems is only possible after further collection and analysis.

For the purpose in mind it was necessary to recognize and to characterize distinct morphotypes. This has been done as far as was possible by a non- specialist. A list of these types with accompanying figures is attached at the end of this paper. The attempt to assign them to systematic groups should be regarded as what it is: the struggle of the unspecialized observer to orientate himself in an overwhelming complexity of forms; doubts are expressed by a profusion of questionmarks accompanying the suggested systematic groups. No attempt has been made to name species, and whenever the term "species" is

(1) - This research was supported by the CNPq, by the Projeto Multilateral "Ecologia da Floresta Tropical" of the Organization of the American States (OAS/OEA), and by a grant of the local government agency SUFRAMA.

(2) - Instituto Nacional de Pesquisas da Amazônia, Manaus, AM. 
used, its should be understood in the sense of "morphotype". The numbers identifying the various morphotypes are a compromise between the process of finding them during analysis of the coliected material and the first impression of similarity with already found types. After much debate $I$ decided to stick to this number system despite its arbitrariness. This was, because the thousands of camera lucida drawings of the primary protocol and of the concocted tables are identified by these numbers, so that re-numbering would certainly have resulted in confusion, besides, renumbering according to supposedly better systematic interpretation would still reflect the degree of ignorance of the observer.

If, in the face of all these shortcomings a dozen pages of this Journal are filled with a list of morphotypes, it is for the following reasons: firstly, to convince the reader that the profusion of forms is not an emanation of my imagination; secondly, to preserve the information - the pristine condition of thase streams may have vanished by the time a dedicated systematist finds time and opportunity to study their thecamoebae fauna; and thirdly, to incite the interest of protozoolcgists in this unique fauna and to provide to future investigations all possible assistence, that may result from this study.

\section{ORGANISMS, SAMPLING SITES AND METHODS}

THE THECAMOEBAE (PROTOZOA, RHIZOPODA)

The thecamocbae are prevalently fresh water organisms; they also occur in moist, terrestrial habitats (soils, mosses, epiphytes ect); they are less common in marine environments. Unlike their marine relatives, the Foraminifera, which secrete tests of calcium carbonate, the thecamoebae construct their tests, or thecae, of particles selected in their environment (mostly sand), which they glue together with chitinous excretions. The relative amount of foreign particles and secretion varies greatly; the thecae of the enormous genus Diffugia, for instance, consist of sand except for the minimum of excretion necessary to glue the particles together, whereas Nebeliidae use virtually no foreign particles, indeed, this family and the Euglyphidae secrete as accomphished, geometric, proteinous thecae as do the calcareous Foraminifera. The construction of thecae is specific to genera and species, as may be verified in any introductory text to Protozoa (for instance Kudo, 1966). Description of species relies often on the characteristics of the test alone, as the living cell may never have been observed.

According to Cailleux (1978) and Decloitre (1964-1976) the total number of thecamoebae species and varieties described, worldwide, until 1975, is about 1600 ; only 78 were, until then, reported from Brasil, some of which are reported in a recent atlas of thecamoebae (Ogden \& Hedley, 1980). Later, Bonnet (1979) described some soil amoebas from Brasil. I have no knowledge of a published report on Amazonian thecamoebae.

The material presented in this study was collected in the fine, organic detritus that accumulates on the sandy bottom of streams in places of low water flow. This detritus consists largely of faeces of aquatic insect larvae which live in submerged leaf litter. As was verified by spot checks, thecamoebae occur also on the surfaces of dead, submerged leaves, on mosses and roots along river banks at high water level etc. However, efficient, quantitative sampling was possible only in the detritus habitat.

Examination of the quantitative samples led to the recongnition of 129 moiphotypes which are presented in a list with accompanying figures. This "List of morphotypes" with 7 Plates is attached to the end of this paper in order to avoid interruption of the text in this chapter. It is an appendix with regard to position only - it is essential for the understanding of the results and the conclusions

\section{THE STREAMS}

The map in Fig. 1 shows the forest region drained by the three river systems Tarumã, Cuieiros and Tarumazinho $(=$ Tarumã-Mi- 
rim in Table 2). This map is re-drawn after the map "Projeto RADAMBRASIL", $1: 250.000$, which, in turn, is based on satellite photographs. Hence, the courses of very small forested streams are not clearly recognizable, the positions of the collection sites should therefore be regarded as approximations. With the exception of some spot checks in the rivers Ypiranga and Tarumãzinho, all collections were made in such very small streams,

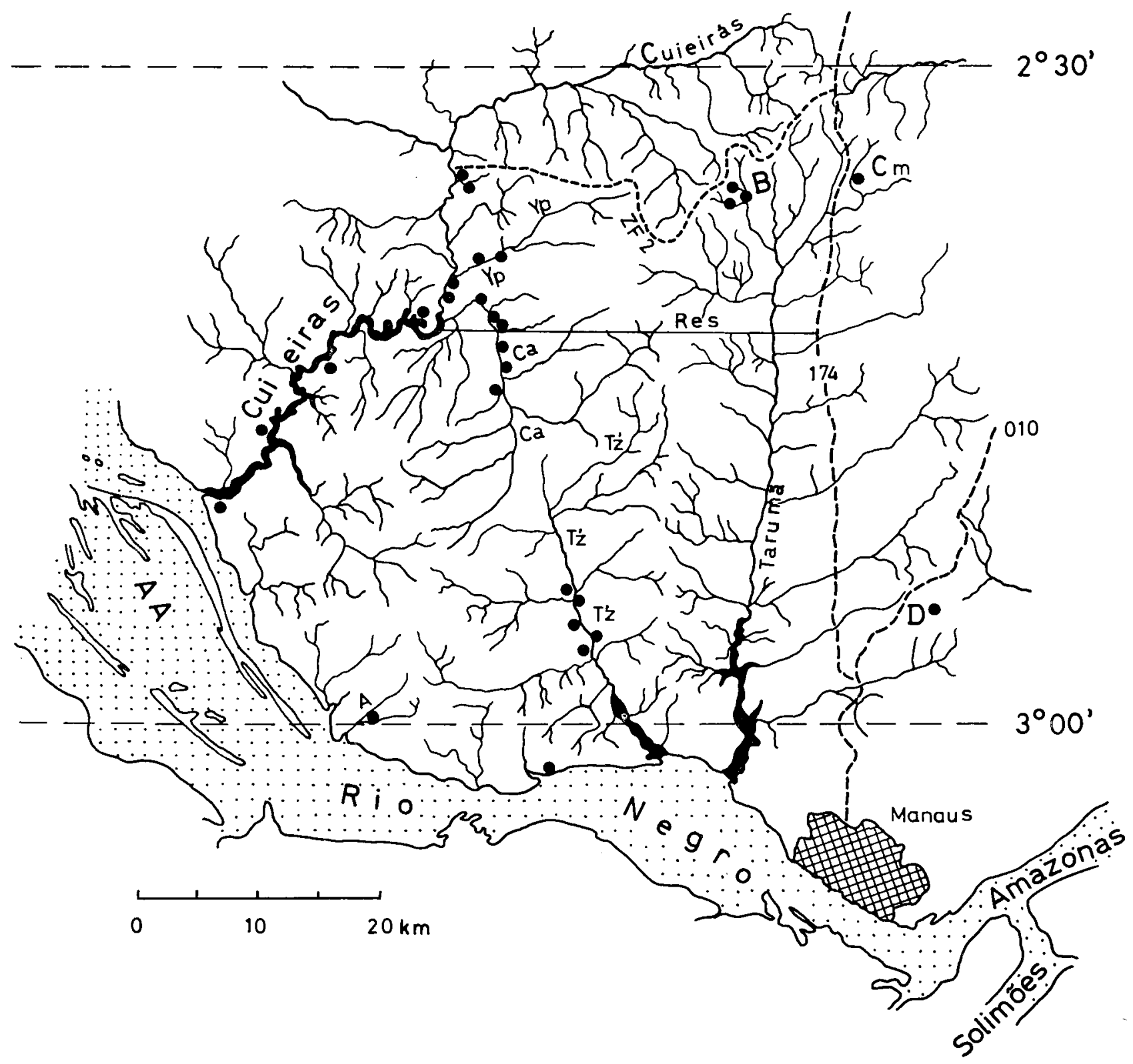

Fig. 1 - Area drained by the three river systems Tarumã, Tarumazinho $(=$ Tarumã-Mirim $=$ little Tarumã $)$ and Cuieiras. $A A=$ Arquipélago das Anavilhanas. $B=$ hydrographic basin with the stream "Igarapé Bacia" and its two tributaries issueing near $\mathrm{Km} 15$ and $\mathrm{Km} 17$ of the road ZF 2. CA = Igarapé da Cachceira. $\mathrm{Cm}=$ forest reserve "Campina" with black water stream "Igarapé da Campina". $D=$ forest reserve "Reserva Ducke" (Km 26 on road 010 to Itacoatiara) with the clear water stream "Barro Branco" draining into Tarumã. Res = southern boundary of the forest reserva "Reserva $\mathrm{Km} \mathrm{60"} \mathrm{(according} \mathrm{to} \mathrm{new} \mathrm{numeration} \mathrm{situatad} \mathrm{at} \mathrm{Km} 45$ of highway BR 174 to Boa Vista). $Y p=$ igarapé Ypiranga. The black dots indicate sample sites of thecamoebae and of other stream fauna not dealt with in this paper (Kensley \& Walker, 1982). Problems with exact position of streams and sampling sites see above. (map after "Projeto RADAMBRASIL" 1: 250,000). 
within the first $1-7 \mathrm{~km}$ of their source. The major collections were carried out between 1978 and 1980 in five streams of the Tarumãsystem; during the high- water period, in June 1978 and 1979, the small tributaries of the "Igarapé (= small river or stream) da Cachoeira" were accessible by boat, and a limited number of samples were taken on these occasions.

The waters of these streams are usually acid and of extremely low conductivity; they are "black" if they drain sandy soils with slow and incomplete decomposition of litter (Cam. pinas, Campinaranas), and "crystalline" or "clear" when draining heavy clay soils. Larger streams are ofien a mixture of black and clear water tributaries, such as the Ig. da Cachoeira and Rio Tarumãzinho. The lg. Ypiranga is completely crystalline. In the following, the five streams of the Tarumã system are enumerated with some data on their water quality $\left(\mathrm{pH}\right.$, conductivity in $\mu \mathrm{S}_{20}$, black or crystalline):

1. "Barro Branco", forest reserve Reserva Ducke, crystalline, $\mathrm{pH}=4.3-4.5,8.4 \mu \mathrm{S}_{20}$; 2. "Ig. da Campina", Reserva km 60, black, $\mathrm{pH}=3.8-40,12.0 \mu \mathrm{S}_{20} ; 3$. "Ig. da Bacia" draining the Bacia Modelo, Reserva km 60 , local road $\mathrm{ZF} 2, \mathrm{~km} 14$, mixed water, $\mathrm{pH}$ $4.4 \pm 0,8,13.4 \pm 13.4 \mu S_{20}$ (repeated data over longer periods provided by Dr. W. Franken); 4. " $/ \mathrm{g} . \mathrm{km} \mathrm{15",} \mathrm{tributary} \mathrm{of} \mathrm{the} \mathrm{lg}$. da Bacia, crystalline, $\mathrm{pH}=4.9,9.9 \mu \mathrm{S}_{2}$ (single determinations); 5 . " $/ \mathrm{g} . \mathrm{km} \mathrm{17",} \mathrm{tributary} \mathrm{of}$ the Ig. da Bacia, crystalline, $\mathrm{pH}=5.0,17.2$ $\mu S_{20}$ (single determinations, Oct. 26. 1981, same day as for $\mathrm{lg} . \mathrm{km} \mathrm{15).}$

There seems to be considerable variation in the nature of the organic detritus in these streams. The colour of detritus in the black water stream of the Campina is a dark redbrown, whereas detritus of clear streams is lighter and, in some cases, almost greyishbrown, as for instance in the Barro Branco. Campina detritus contains $100-150 \%$ more humic acid than Barro Branco detritus and the ratios of humic: fulvic acid is $\pm 80: 20 \%$ in the Campina detritus and 90: $10 \%$ in Barro
Branco detritus (single, aproximate determinations by Dr. J. Leenheer; see also Leenheer 1980).

\section{METHODS}

Sampling. A detailed description and critical analysis of the sampling method was published previously. (Walker \& Lages, 1980). Samples of approximately $8 \mathrm{ml}$ of detritus and sand were collected at distances of 6 to 12 meters in up- stream direction in series of usually 12 such samples. In the laboratory the material was placed in petri dishes under a low- power microscope, and I allowed myself $10 \mathrm{~min}$ to search for and to remove, unbroken thecae from this substrate. In the text, this 10- min- sample is referred to as "the sample". The number of thecae removed is proportional to the density of thecae per volume of substrate, (i. e. per volume of settled detritus in aqueous suspension, the dry weight of which is less than $100 \mu \mathrm{g} / \mathrm{ml}$ (including sand), thus, these samples reveal the relative density of thecae between streams. Series of 10. minremovals from a single sample allow for the approximate calculation of the absolute density of the thecae. After the 10- min- removal the thecae were examined under the hingh power microscope, assigned to various morphotypes and, whenever it seemed necessary or desirable, traced via camera lucida. Special attention was given to amoebae that were alive and active under the microscope.

Documentation: Camera lucida drawings were made invariably at the microscopic magnification of $160 \times$ and under fixed camera lucida setting with the exception of some very small forms which were drawn at higher magnifications. However, this necessitates observation under oil immersion, and this was not always possible during quantitative analysis. For this reason, some of the smallest forms are not adequately documented by drawings. Series of camera lucida drawings were transferred to tracing paper with a japanese felt brush. This "catalogue of morphotypes" displays the range of variation of the frequent types and a complete record of the forms that appeared only a few times. 
Details shown in these drawings inciude largest and smallest identifyable paritcle size with their typical distribution in tests constructed with sand, and in the Euglyphidae, the patterns of the hyaline test. (Copies of this catalogue will be deposited in the Invertebrate Collection, Divisão de Entomologia, INPA, and in the "Archives du service de documentation" of the CNRS, 15 Quai Anatole France, Paris).

From this catalogue the here published documentation of a total of 129 morphotypes was extracted, namely a "list of morphotypes" with accompanying figures on seven plates (Figs. 5-11), both attached at the end of this paper with the necessary explanations. The information given by text and figures is complementary, what is evident from the figures is not repeated in the text unless for special reason. The arrangement of the morphotypes on the plates is a compromize between numbered sequence of types, systematic position and graphical necessity. In the list of morphotypes the plate number is indicated only for those which are difficult to localize. (See also pp. 90, 91-103).

Presentation of results: Tables and figures with accompanying explanations should need no further comment on methology with the exception of the concept of frequency used to express the abundance of morphotypes.

The larger amoebae and ciliates from amazonian waters I have so far observed, and occasionally bred over long periods (Walker, 1978), all show a similar population behaviour, in that they move around randomly without reproduction for several days in absence of food, or if food is scarce; yet when meeting with a food source they stay in this place and reproduce intensely, presumably as long as the food is adequate (also several days). A single detritus sample may thus contain several individuals of a rare species and still be deficient in frequent species For this reason, the frequency of morphotypes is not given in percent of individuals recovered, but in percent of samples in which the morphotypes appeared.

\section{RESULtS}

\section{QUANTITATIVE ANALYSIS}

\section{Abundance and distribution of thecamoebae}

Sequence of sampling and appearance of new morphotypes. Fig. 2 relates the finding of new morphotypes to the sequence of sampling and to the magnitude of samples. It is evident that a series of 12 samples contains the majority of species present in a given area $(100-200 \mathrm{~m}$ along stream) at a particular time. However, if such series are repeated at intervals of several months, a considerable number of new types appears; only after the third series does the cumulative curve of the Ig. da Bacia level off. Thus, we would still expect some new species in each stieam with further sample series. The parallel condition of the two curves (Bacia, Barro Branco) is reassuring: it means firstly, that two streams with approximately similar numbers of samples can be compared; and secondly, that the rise in the number of species is not simply reflecting the learning process of the observer.

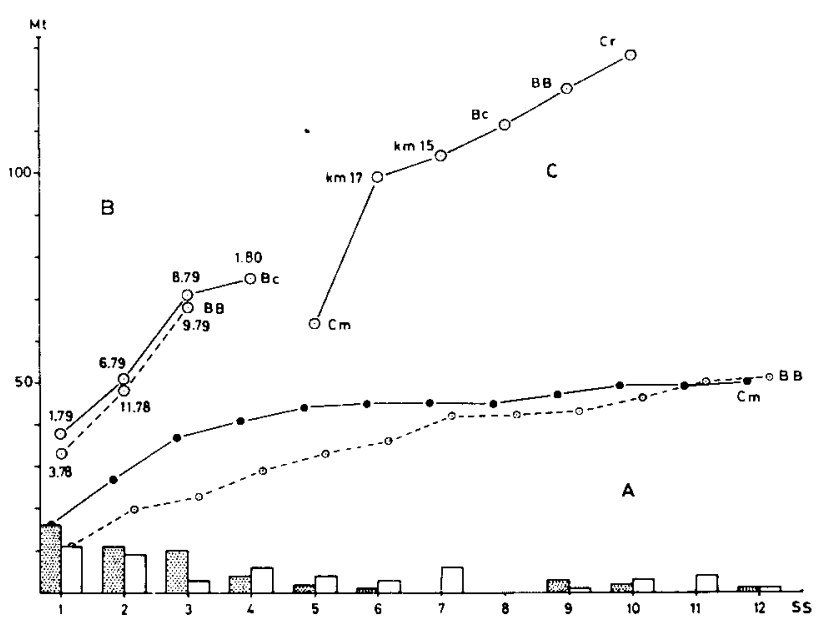

Fig. 2 - Appearance of numbers of new morphotypes (Mt) in consecutive samples (SS). A: new morphotypes in samples (columns) and cumulative curves within a single sample series of the streams Barro Branco (BB) and $\lg$. da Campina $(\mathrm{Cm})$. B: cumulative curves of repeated sample series (of 12 samples each) of the streams Barro Branco and Ig. da Bacia $(B c)$; numbers near circles indicate month and year of sampling. $\mathrm{C}$ : increase of morphotypes with each new stream sampled (3-4 series of 12 samples each); $\mathrm{Cr}: 32$ samples of the Cuieiras system (Igarapés da Cachoeira and Ypiranga). 
TABLE 1 - Frequency distribution of the 119 morphotypes recovered in a total of 191 samples from the 5 streams of the Tarumã system.

\begin{tabular}{|c|c|c|c|c|c|c|c|c|c|c|c|c|c|c|c|c|c|}
\hline \multirow[b]{2}{*}{1} & \multirow[b]{2}{*}{2} & \multicolumn{6}{|c|}{$\begin{array}{l}\text { Rare species: } n .^{\circ} \text { samples containing morphotype } \\
\qquad=0.5-5 \% \text { of } 191 \text { samples })\end{array}$} & \multirow[b]{2}{*}{9} & \multirow[b]{2}{*}{10} & \multicolumn{8}{|c|}{ More frequent species: \% — classes of 191 samples } \\
\hline & & 3 & 4 & 5 & 6 & 7 & 8 & & & $5-10$ & -20 & .30 & -40 & .50 & -60 & -70 & 8.0 \\
\hline 1.2 .1 & 1.1 .2 & 5.4 & 7.14 & 5.8 & 10.1 .1 & 7.6 & 5.6 & 7.19 & 10.4 .1 & 1.1 .1 & 6.2 & 1.1 & 1.3 & 3.3 & 3.1 & 7.5 & 1.2 \\
\hline 5.2 .1 & 3.3 .1 & 7.2 & 8.2 .1 & 10.4 & 10.10 .1 & 8.3.1 & 5.7 & 9.6 & & 9.5 & 8.5 & 2.2 & 1.5 & 4.2 & 5.1 & 10.1 & \\
\hline 7.9 & 5.5 & 7.11 & 9.5 .1 & & 10.12 .2 & & 6.1 & 10.23 & & 10.8 & 1.4 & 2.3 & & & 10.5 & & \\
\hline 7.13 & 7.8 & 7.11 .1 & 10.12 .1 & & & & 8.4 & & & 10.12 & 1.6 & 3.2 & & & & & \\
\hline 7.20 & 9.7 & 7.17 & 10.18 .1 & & & & & & & 7.16 & 2.1 & 5.3 & & & & & \\
\hline 7.22 & 10.2 .1 & 10.2 & 10.19 & & & & & & & 9.2 & 3.2 .1 & 7.3 & & & & & \\
\hline 8.6 & 10.7 .1 & 10.4 .3 & & & & & & & & 1.3 .1 & 3.4 & 8.2 & & & & & \\
\hline 9.8 & 10.8 .1 & 10.10 .3 & & & & & & & & 3.4 .1 & 4.1 & 9.1 & & & & & \\
\hline 10.7 & 10.9 .1 & 10.17 & & & & & & & & 6.3 & 4.3 & 9.3.1 & & & & & \\
\hline 10.13 & 10.16 & 10.18 & & & & & & & & 10.10 & 5.2 & 9.4 & & & & & \\
\hline 10.14 & 10.19 .1 & 10.20 & & & & & & & & 10.15 & 7.1 & & & & & & \\
\hline 10.21 & & 10.24 & & & & & & & & 10.6 & 7.7 & & & & & & \\
\hline 10.22 & & 10.24 .1 & & & & & & & & 9.9 & 7.12 & & & & & & \\
\hline 10.4.2 & & 8,0 & & & & & & & & 7.21 & 7.15 & & & & & & \\
\hline 10.6.1 & & & & & & & & & & 10.21 & 8.7 & & & & & & \\
\hline 10.7 .2 & & & & & & & & & & & 8.5 .1 & & & & & & \\
\hline 10.10 .1 & & & & & & & & & & & 9.3 & & & & & & \\
\hline 10.20 .1 & & & & & & & & & & & $\begin{array}{c}9.3 .2 \\
9.3 .3\end{array}$ & & & & & & \\
\hline 18 & 11 & 14 & 6 & 2 & 3 & 2 & 4 & 3 & 1 & 15 & 20 & 10 & 2 & 2 & 3 & 2 & 1 \\
\hline
\end{tabular}

N.' morphotypes in Frequency class 
because the second point of the Barro Branco was determined almost a year before the first point of the "Bacia". The strong rise before Aug. - Sept. 1979 is also characteristic of the Campina stream (Table 2) and is due to an increase of the number of small euglyphid types after an exceptionally long, hot and dry season.

The cumulative curve for individual streams as samples shows that any collector of thecamoebae can expect a fair number of additional species with each stream sampled, and this even in the proximity of Manaus alone.

The reasonableness to expect new species with repeated sample series is also shown by the values of the index of diversity (Williams' $\alpha$, Table 2): the index of the totals is larger than that of the individual sample series (Southwood, 1979; Williams, 1947).

Frequency of morphotypes (Table 1). It is not surprising, then, that 18 of a total of 119 types in the 5 Tarumã- streams, that is $15.1 \%$ of the types described for this river system, appear only in a single sample, and that the fraction of rare species $(0,5-5 \%$ of samples $)$ is $79 / 119=66.3 \%$. These results mean that some caution must be exercised when the quantitative spectra of species are compared between streams. With the present sampling conditions, even two streams with ideally identical species inventories could not show this by an identical list of morphotypes.

The highest abundances of types in terms of individuals per population sampled in a given stream, 'were reached by type 1.2 in the Campina stream with $12.6 \%$ of all thecamoebae typed and counted, and by type 7.5 in the Bacia stream with $13.6 \%$.

Pattern of distribution in space (Fig. 3). Not everything is pure probabilistics, though. If we regard the relation between means $(\bar{x})$ and variance $\left(\mathrm{s}^{2}\right)$, bearing in mind that in case of random distribution we expect $\bar{x}=s^{2}$, we find that density of individuals is clumped $\left(s^{2}>\bar{x}\right)$, whereas number of morphotypes per sample has a tendency to regularity $s^{2}<\bar{x}$. Both deviations from randomness are highly

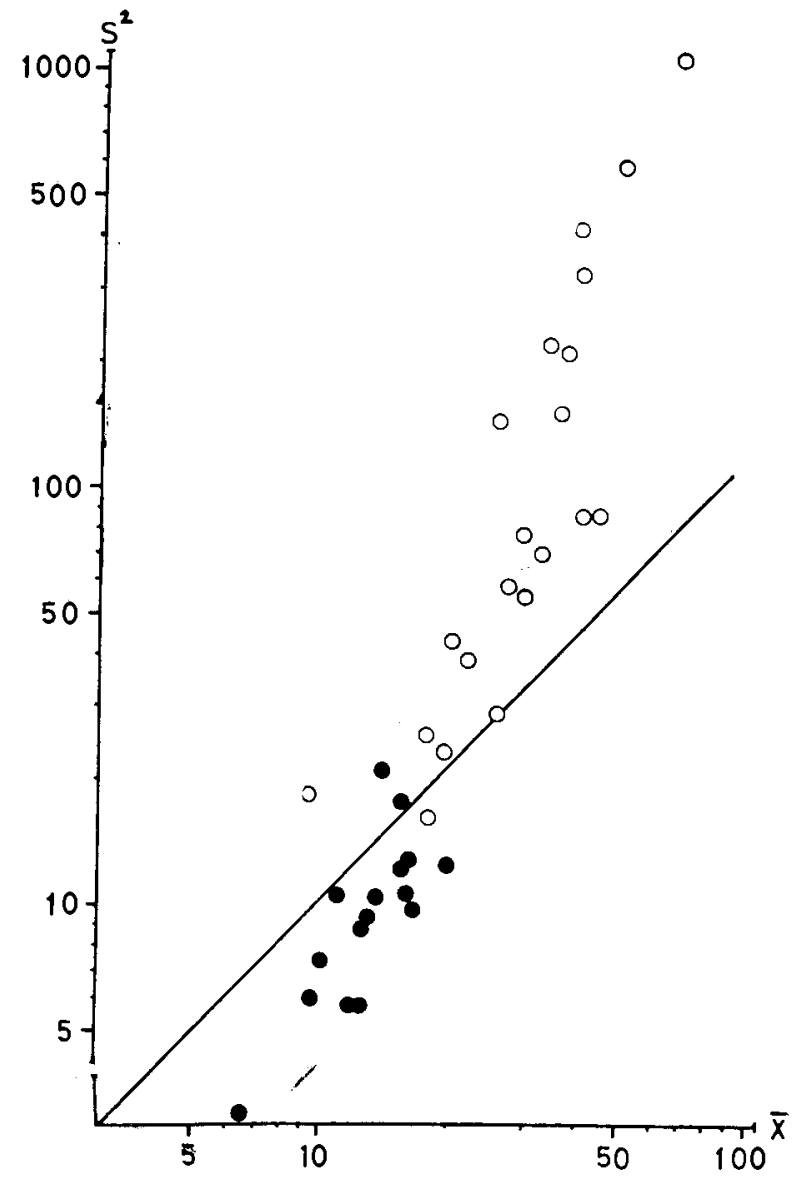

Fig. 3 - Pattern of distribution. $s^{2}=$ variance and $\bar{x}=$ mean of 12 samples each, open circles showing number of thecamoebae with tendency to clumping (concentration above $45^{\circ}$ - line), and black circles showing number of morphotypes with tendency towards overdispersal (concentration below $45^{\circ}$-line).

significant $P<0.01$, sequential analysis, (Documenta Geigy, 1960). This pattern of distribution may be explained in biological terms. Microorganisms tend to multiply opportunistically and rapidly on an accidental food source. The higher the overall population density, the more individuals and the more morphotypes will be found near such a food source. The experimental, and purely local, rise of population density in this area will reduce the chance of a later arrival to build up a population boom of its own type. In case of low population density, exponential build- up of local population density of accordingly less morphotypes will still prevent late, new arrivals to proliferate on the spot. These conditions result in the pattern observed: increased 
tendency to clumped distribution of individuals with increased density $(\bar{x})$, but con. sistent tendency towards regularity in number of morphotypes, regardiess of their mean number.

These conditions may slightly distort comparative data between streams of high and low density of thecamoebae, specifically in case of too few samples (which does not apply in our case, though). For instance the mean number of morphotypes per- sample in the Barro Branco series ranges from 6.5 - 13, and in the Campina stream from $10-16$ only, despite the fact that density of individuals is $3-5$ times higher in the Campina, and that the total number of morphotypes is almost equal in the two streams (Table 2).

\section{Comparison between streams}

Density and diversity (Table 2). All precautions taken, we may proceed to compare the thecamoebae faunas of the various streams.

Neither the data in Table 2 nor the foregoing considerations (Fig. 2 etc) allow for the assumption that the total number of morphotypes recovered per stream varies between streams $(P>0.15$, sign test $)$. To the contrary, the values are remarkably similar, particularly so if we consider that the highest value ( $\mathrm{kg}$. da Bacial is based on a higher number of samples (41 as opposed to 36 in the other streams). The striking difference between streams lies in the density of their populations. Only the difference between the "Bacia" and its two tributaries " $\mathrm{Km} \mathrm{15"} \mathrm{and} \mathrm{"} \mathrm{Km} \mathrm{17"} \mathrm{is}$ insignificant $(P>0.05)$, the probabilities for similarity of density is below 0.05 for any other two streams, and for the "Campina" and Barro Branco it is less than $1 \%$ (Sign tests). These differences seem to be correlated with the "blackness" of the water. Black water is several times richer in thecamoebae than crystalline water, whereas the mixed water of the Ig. da Bacia shows an intermediate value. The few data of the Cuieiras system are in this repect in complete agreement with those of the Tarumã- system. It is possible, that higher conductivity, that is, higher mineral content, also favours population density to some extent, this may account for the higher value in " $\mathrm{km} \mathrm{17"} \mathrm{than} \mathrm{in} \mathrm{"} \mathrm{km} \mathrm{15",} \mathrm{but} \mathrm{the}$ difference is not significant, and single determinations of conductivity do not allow for conclusions to be drawn (see p. 82).

The combination of similar number of species and massive difference in density results in marked variation of the index of diversity (Williams' $\alpha$ ) between streams.

Similarity (Fig. 4, Table 3). Considering all morphotypes in Table 1, the rare and frequent ones, comparison of similarity between streams (Fig. 4) would agree with a compromise between geographic distance (Fig. 1) and water quality. The closest simiiarities are found within the hydrographic basin, between the three streams "Bacia", "km 15" and "km 17". Let us remember that the high frequency of rare species and the expectation of new species still to be found, do not allow for $100 \%$ common species, even in case of theoretical identity of two streams. The Ig. da Bacia is equally simiiar - or dissimilar- to the Barro Branco and the Ig. da Campina, although, geographically, it is much nearer to the latter. The Campina stream is as different from " $\mathrm{km} \mathrm{15"} \mathrm{as} \mathrm{from} \mathrm{the} \mathrm{much} \mathrm{remoter} \mathrm{Bar-}$ ro Branco; but then the waters of Barro Branco and " $\mathrm{km} \mathrm{15"} \mathrm{are} \mathrm{quasi} \mathrm{identical} \mathrm{as} \mathrm{far} \mathrm{as}$ tested (p. 82).

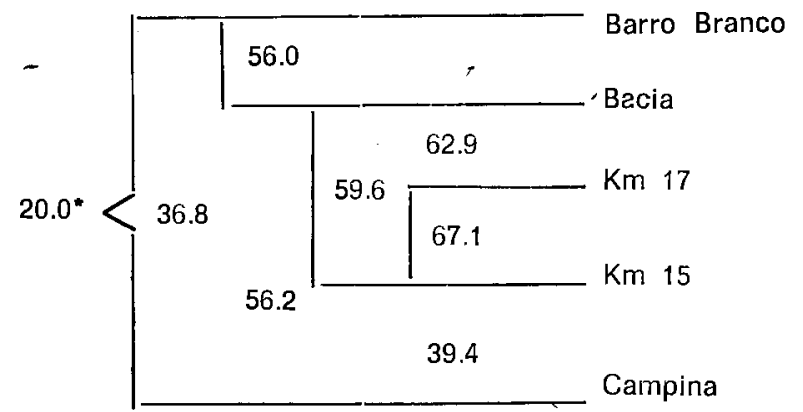

Fig. 4 - Morphotypes common to two streams in \% of total number occuring in the two streams represented by the branches flanking the numbers. " : \% morphotypes common to all 5 streams of the Tarumã system. 
TABLE 3 - Frequency of morphotypes in amazonian streams in $\%$ of samples (n = 100\%) that contain morphotype. $\mathbf{m}=$ total number morphotypes found in stre am, and river system as a whole (Tarumã, Cuieiras); $\mathbf{m}_{10}=$ number morphotypes with a frequency of $\geq 10 \%$; only those morphotypes are considered that appeared at least in one stream with a frequency of $\sim 10 \%$. Thick-set, spaced numbers: frequencies of $>45 \%$. Blanks: morphotype absent. One, 2 or 3 dots: type present in 1,2 os 3 samples (adding up to less than $10 \%$ ).

\begin{tabular}{|c|c|c|c|c|c|c|c|c|}
\hline Types & $\begin{array}{c}\text { Stream } \\
\mathrm{m}_{10} / \mathrm{m} \\
\mathbf{n}\end{array}$ & $\begin{array}{c}\mathrm{Km} 15 \\
31 / 67 \\
35\end{array}$ & $\begin{array}{c}\mathrm{Km} 17 \\
33 / 72 \\
36\end{array}$ & $\begin{array}{c}\text { Bacia } \\
45 / 76 \\
41\end{array}$ & $\begin{array}{c}\text { Campina } \\
29 / 64 \\
42\end{array}$ & $\begin{array}{c}\text { Barro Branco } \\
24 / 67 \\
37\end{array}$ & $\begin{array}{c}\text { Tarumã } \\
41 / 119 \\
191\end{array}$ & $\begin{array}{c}\text { Cueiras } \\
35 / 73 \\
32\end{array}$ \\
\hline 1.1 & & 11.4 & 22.2 & 19.5 & 19.0 & 30.0 & 20.2 & \\
\hline 1.1 .1 & & & $\cdot$ & 22.0 & . & & 5.8 & . \\
\hline 1.2 & & 62.9 & 86.1 & 51.0 & 73.8 & 78.5 & 70.2 & 68.8 \\
\hline 1.3 & & 28.6 & 66.7 & 41.5 & 16.7 & 21.5 & 34.6 & 34.4 \\
\hline 1.3 .1 & & . & . . & 22.0 & & . & 7.3 & \\
\hline 1.4 & & . & 36.1 & 22.0 & & . & 12.6 &. \\
\hline 1.5 & & 37.1 & 38.9 & 54.5 & 11.9 & 49.0 & 37.7 & 50.0 \\
\hline 1.6 & & & & & 59.5 & & 13.1 & \\
\hline 2.1 & & & & & 50.0 & 16.0 & 14.1 & \\
\hline 2.2 & & 54.3 & 27.8 & 12.0 & & 35.0 & 24.6 & 37.5 \\
\hline 2.3 & & 34.3 & 47.2 & 27.0 & . &. & 23.0 & . . \\
\hline 3.1 & & 37.1 & 30.6 & T6. 5 & 90.1 & 49.0 & 58.1 & 56.3 \\
\hline 3.2 & & 14.3 & 36.1 & 24.5 & 31.0 & 19.0 & 25.1 & 18.8 \\
\hline 3.2 .1 & & 31.4 & . . & 20.5 & & . . & 12.6 & \\
\hline 3.3 & & 51.4 & 52.8 & 68.0 & 11.9 & 46.0 & 65.6 & 34.4 \\
\hline 3.4 & & & & $\cdot \cdot$ & 73.8 & & 17.8 & 18.8 \\
\hline 3.4 .1 & & & 25.0 & . . & $\cdot \cdot$ & & 7.3 & 12.5 \\
\hline 4.1 & & 20.0 & 33.3 & 24.5 & & . . & 16.2 & \\
\hline 4.2 & & 82.9 & 36.1 & 56.0 & . & 56.7 & 45.6 &. \\
\hline 4.3 & & 11.2 & 33.3 & 19.5 & . & . & 14.1 & 18.8 \\
\hline 5.1 & & 80.0 & 83. 3 & 41.5 & & 70.3 & 52.9 & 25.0 \\
\hline 5.2 & & 14.3 & 25.0 & 29.0 & & & 13.6 & 18.8 \\
\hline 5.3 & & 11.4 & 27.8 & 66.0 & 14.3 & 21.5 & 28.8 & \\
\hline 5.7 & & - & & & 14.3 & . & & \\
\hline 6.1 & & - & & 12.0 & . & . & 4.2 & 9.4 \\
\hline 6.2 & & . & 22.2 & 24.5 & . & & 11.0 & 18.8 \\
\hline 6.3 & & & & & 33.3 & & 7.3 & 12.5 \\
\hline 7.1 & & . . & 50.0 & 32.0 & . . . & . & 19.9 & 9.4 \\
\hline 7.3 & & 17.1 & . & 22.0 & 57.1 & . & 23.0 & 9.4 \\
\hline 7.5 & & 40.0 & 86.1 & 98.0 & 47.6 & 30.0 & 60.7 & 43.8 \\
\hline 7.6 & & & & . & & 16.0 & 3.7 & \\
\hline 7.7 & & 37.1 & 30.6 & 12.0 & . . & & 16.2 & . \\
\hline 7.12 & & 22.9 & 41.7 & 14.5 & & 21.5 & 19.4 & \\
\hline 7.15 & & 22.9 & 19.4 & 49.0 & & & 18.3 & 18.8 \\
\hline 7.16 & & & . & . . & 23.8 & & 6.8 & \\
\hline 7.19 & & & & & 21.4 & & 4.7 & 12.5 \\
\hline 7.21 & & . . & . & 27.0 & . . . & . & 10.0 & 9.4 \\
\hline 7.21 .1 & & & & & & & & 9.4 \\
\hline 8.1 & & & & & & 11.0 & 2.1 & . \\
\hline 8.2 & & 14.3 & 13.9 & 39.0 & 50.0 & 16.0 & 27.8 & 28.1 \\
\hline 8.3 & & 51.4 & 83.3 & 64.0 & 73.8 & & 59.7 & 25.0 \\
\hline 8.3 .1 & & & . & . . & & . . & 3.7 & 25.0 \\
\hline 8.5 & & • & 16.7 & 27.0 & . . & . & 11.0 & 9.4 \\
\hline 8.5 .1 & & 14.3 & . . . & 27.0 & & . & 10.5 & 18.8 \\
\hline 8.7 & & • & $\cdot$ & 10.0 & 26.2 & . & 10.5 & 12.5 \\
\hline 9.1 & & 51.4 & 19.4 & 22.0 & & 27.0 & 23.0 & 12.5 \\
\hline 9.2 & & . & 22.2 & . . & . & . & 6.8 & \\
\hline 9.3 & & 14.3 & 47.2 & 34.0 & & . & 19.3 & \\
\hline
\end{tabular}

The thecamoebae... 
TABLE 3 (Continuation).

\begin{tabular}{|c|c|c|c|c|c|c|c|c|}
\hline Types & $\begin{array}{c}\text { Stream } \\
m_{10} / m \\
n\end{array}$ & $\begin{array}{c}\mathrm{Km} 15 \\
31 / 67 \\
35\end{array}$ & $\begin{array}{c}\mathrm{Km} 17 \\
33 / 72 \\
36\end{array}$ & $\begin{array}{c}\text { Bacia } \\
45 / 76 \\
41\end{array}$ & $\begin{array}{c}\text { Campina } \\
29 / 64 \\
42\end{array}$ & $\begin{array}{c}\text { Barro Branco } \\
24 / 67 \\
37\end{array}$ & $\begin{array}{c}\text { Tarumã } \\
41 / 119 \\
191\end{array}$ & $\begin{array}{c}\text { Cueiras } \\
35 / 73 \\
32\end{array}$ \\
\hline 9.3 .1 & & 60.0 &. & 37.0 & & . & 21.0 & 43.8 \\
\hline 9.3 .2 & &.. &. & 29.0 & & 19.0 & & 12.5 \\
\hline 9.3 .3 & &. & . & 46.5 & & 16.0 & 15.2 & 9.4 \\
\hline 9.4 & & 82.9 & & 12.0 & & 21.5 & 23.0 & \\
\hline 9.5 & & . . . & & 10.0 & & 13.5 & 6.3 & . \\
\hline 9.6 & &.. & . & & & . & 4.7 & . \\
\hline 0.9 & & & & & 42.9 & & 9.2 & \\
\hline 10.1 & & 74.3 & 72.2 & 63.5 & 66.7 & 40.5 & 63.4 & 9.4 \\
\hline 10.3 & & 31.4 & 52.8 & . & & . . & 17.3 & \\
\hline 10.4 .1 & & & & & 21.4 & & 5.2 & . \\
\hline 10.5 & & 40.0 & 66.7 & 90.0 & 16.6 & 49. 0 & 52.4 & 12.5 \\
\hline 10.6 & & . . & 19.4 & . . & 9.5 & . & 8.9 & • \\
\hline 10.8 & & & . & 14.5 & 9.5 & 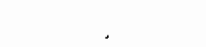 & 6.3 & \\
\hline 10.10 & & . • & , & & 26.2 & & 7.3 & . . \\
\hline 10.10 .2 & & . & . & 10.0 & & & 3.1 & \\
\hline 10.12 & & . & $\therefore$ & . & 19.0 & & 6.3 & . . \\
\hline 10.15 & & . & . . &.. & 11.9 & . & 7.3 & 12.5 \\
\hline 10.23 & & & & 14.5 & $\cdots$ & & 4.7 & \\
\hline
\end{tabular}

In Table 3 the rare species are excluded, only those morphotypes are considered that occur with a frequency of about $10 \%$ (cf samples! see p. 83) in at least one stream. Even then, the Campina stream and Barro Branco have the lowest percentage of morphotypes in common $(51 \%)$, followed by "Campina" and "Bacia" (54\%), whereas Barro Branco and "Bacia" are much more similar (79\%). Apparently, some rather frequent species are absent from original, non- mixed, black water as that from "Campina". This is conspicuously true for centropyxid forms (types 9.1 - 9.6), for type 5.1 and for the two granulo- reticulose types 4.1 and 7.2. The streams of the hydrographic basin are almost identical $(92 \%$ for "Bacia" and "km 17" for example).

Table 3 is far too complex to be trans. lated into words, but a few conspicuous differences may be pointed out. Type 1.6 is exclusive to the Campina stream; the frequent type 4.2 is virtually absent from the "Campina"; types 3.4 and 3.4.1 were found in black water only. Black water is particularly rich in Euglyphidae; type 9.4 was not found in the Cuieiras system, nor were types 4.1 and 7.12 (Granuloreticulosa (?)).
A few observations point to interesting questions with regard to speciation, in that closely related forms are separated by river basins. Thus types 2.1 and 2.2 for the hydrographic basin and the "Campina"; types 3.4 and 3.4.1 are almost separated between these two basins; type 7.21.1 is specific to the Cuieiras system, but 7.21 is found in both river systems, Cuieiras and Tarumã. Some observations not shown in this table may be mentioned in this context: the dozens of drawings made via camera lucida indicate that the proportions and/or sizes vary between the Tarumã and Cuieiras systems for the forms $4.2,6.1$ and 2.2 ; and for type 10.1 between the hydrographic basin ("Bacia", "km 15", "km 17") and the "Campina".

\section{BIOLOGICAL OBSERVATIONS}

Accumulation of empty thecae or biological pattern? Only a fraction of the collected thecae contained a living cell, although many more than noted in the list of morphotypes, where living organisms are mentioned only in cases of extended pseudopods or of food vacuoles with recognizable content. It may be 
argued, therefore, that the material sampled represents an accumulation of dead, empty thecamoebae without any relation to the actual living population. The following observations speak against this interpretation: 1 . Organic detritus is light and is washed away with heavy rains; 51 morphotypes were found in 60 samples collected in free water after a heavy rain in the lg. da Cachoeira; this shows that the thecamoebae get washed away together with the detritus. 2. Empty thecae do not accumulate on the sandy substratum; samples poor in detritus and rich in sand are usually also poor in thecamoebae. 3. empty thecae do not accumulate in the zone of accumulation of light sand particles and of detritus in the meanders in the larger streams (for instance 5 samples of the Rio Tarumazinho showed a mean of $16 \pm 5.3$ thecae, included all broken ones). 4. The paitern of distribution in Fig. 3. and the pertinent comments on p. 83. 5. The correlation between water quality and density of thecamoebae.

All these observations do not exclude the possibility that some specimens might get washed into the streams from overhanging vegetation and from surrounding soils. A few such samples in the vicinity of the Campina stream turned up one specimen each of types $7.21,8.5 .1,10.12$ and 9.3 .2 (also recovered alive from stream detritus!), and 3 specimens of type 8.7 .

Still, all observations taken together point to the likely conclusion that the thecae recovered from stream detritus are characteristic for a population living in this substrate, and that empty thecae decay rapidly, probably as a result of decomposition of their proteinous fraction.

Feeding behaviour and trophic position. All living amoebae observed, with the exception of types 3.3, 4.1 and 7.12 (Granuloreticulosa (?)), carried food vaculoes with clumped, brown material. The handy conclusion that offers itself is, that they are "detritus feeders". Observations of several dozen active cells under the microscope, though, show a very different picture. If an extended pseudopod touches a clump of detritus, its plasma flux accelerates in that direction, and the entire amoebae may glide into this substrate. Its pseudopods then probe through this material, a multitude of particles gliding along their plasma margin towards the pseudostome. However, only the meticulously selected particles mentioned in the list of morphotypes get ingested, the bulk of the detritus is rejected before it enters the pseudostome. The overwhelmingly favoured particles were bits ct fungus hyphae and spores, and to a lesser extent living diatoms and small euglyphids (see p. 104).

The fungus material in detritus is, according to numerous observations, undoubtedly the same as that found within dead, submerged leaves. These fungi are aquatic leaf decomposers, and the 18 morphotypes (and probably many more as judged from the general similar appearance of the contents of food vacuoles) of thecamoebae, that were found ingesting them, must be regarded as primary consumers. Their prodigious density, notably in black waters, suggests that thecamoebae lend no support to Janzen's (1974) theory of the toxicity of amazonian black water.

\section{General Conclusions}

Sampling for the "normal" thecamoebae fauna of a stream: A series of $10-12$ "tenminutes- samples" (Walker \& Lages, 1980) is sufficient to characterize the thecamoebae fauna of a particular stream over an extension of $100-200 \mathrm{~m}$ at a particular time, and six such series at 2- monthly intervals should reveal the "normal" spectrum of diversity and abundance of morphotypes of a particular stream. With this sampling proceedure, detection of $70-80$ morphotypes would indicate the normal abundance of species in a small, undisturbed, central amazonian forest stream (area drained $\leqslant 8 \mathrm{~km}^{2}$ ).

Thecamoebae as indicator organisms for water quality: All results of the qualitative 
and quantitative analysis indicate that spectrum and frequency of morphotypes, as well as general density, are dependent on water quality, and that, therefore, populations of thecamoebae and/or single species may be suitable indicators for water quality.

Ecological position: The thecamoebae with identifiable food particles were found to be primarily consumers of fungi which decompose submerged leaf litter and organic detritus of animals which, in turn, live off submerged litter. This points to the important fact that the food web of amazonian forest streams is essentially dependent on decomposition of dead, organic material provided by the forest, rather than on primary production within the streams (algae, water plants). For these reasons deforestation of these drainage basins would have altogether devastating consequences for the fauna of these streams.

Diversity of thecamoebae wordlwide and in the Amazon forest: Cailleux (1978) published a graph in which the number of thecamoebae species known is related to the area studied. This graph includes the roughly 1600 species known up to 1976 and all countries which provided data. This analysis allows for the construction of a fairly reasonable curve, on which the number of known species increases with the size of the area studied. On this curve, 129 morphotypes, the total of our list of morphotypes, corresponds to an area of $30.000-40.000 \mathrm{~km}^{2}$. The real points nearest to 130 species are the total number of species known from Holland $(\sim 140)$, Yugoslavia $(\sim 120)$ or from Scotland $(\sim 130)$ for example. A generous estimate of the area drained by the five Tarumã streams sampled, with their 119 species, is about $30 \mathrm{~km}^{2}$. The low number of species in the countries cited above does not necessarily reflect ignorance about this fauna; a recent revision of the Genus Trinema alone has a bibliography of some 130 publications (Decloitre, 1981).

Thus, the thecamoebae fauna presented in this paper is just one more example for the amazing diversity of organisms in the amazonian forest.

\section{APPÊNDIX}

LIST OF MORPHOTYPES: EXPLANATIONS

The morphotypes are arranged in numerical order, that is, in the historical/semi-systematical fashion explained in the introduction. In the cases of gross, systematic misplacement, the type numbers of other representatives of the respective Family are given in brackets. The attempts to classify the material are based on two documents mainly: an unphished list of the Thecamoebae of the world, by L. Decloitre, on $35 \mathrm{~mm}$ film at the "Archives originales du service de documentation du CNRS", 15 Quai Anatole France, Paris. This list contains the known forms up to 1974, it is filmed in form of separate parts numbered $401-404$ (with sub- sections), and the numbers of the film spools are $38.850,388.876$. Each morphotype is represented by a drawing. The parts with forms similar to the amazonian morphotypes in our list are: 404 Faune Thecamoebienne du monde; 403 Faune Thecamoebienne d'Europe par pays et régions; 404 (6) Faune thecamoebienne du monde, espèces nouvelles. The second document consulted for classification was "Treatise on invertebrate paleontology". Vol. 1, the Chapter "Thecamoebians" by A. R. Loeblich \& H. Tappan (1978).

In the list of morphotypes, the source led to identification is indicated in parenthesis: (Moore 1978), (Decloitre 404); doubts are expressed by a question mark.

All authentic observations on live material are reported, and the number of amoebae to which the observations refer are given in parenthesis. With the exception of the very small forms all morphotypes are represented by figures drawn to scale by means of the camera lucida (Plates $1-7$ ). Approximate measures given in the list are therefore added merely to facilitate comparison with descriptions from the literature. Measurements and abreviations: Given are the two largest diameters (or their range) at right angles, and CS (for Cross- Section) indicates whether the section through the horizontal plane along the 


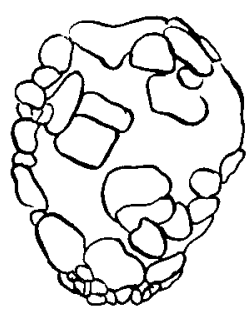

1.4

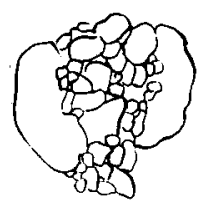

3.1

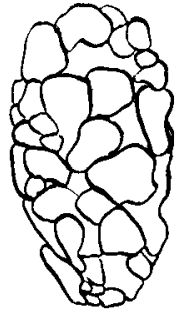

1.5

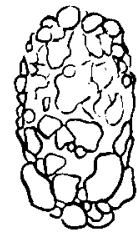

1.6

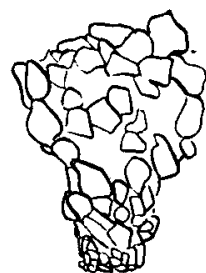

2.1

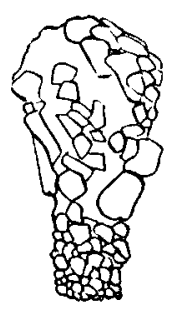

2.2

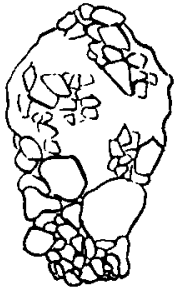

2.3

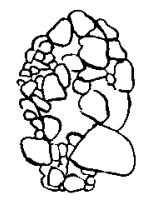

3.1

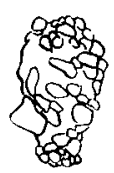

3.2

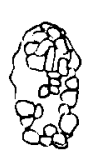

3.2 .1

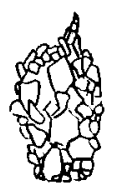

3.6

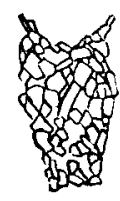

3.4 .1

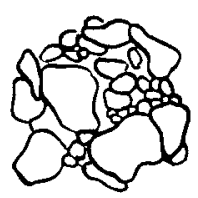

3.3

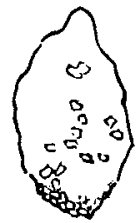

7.12
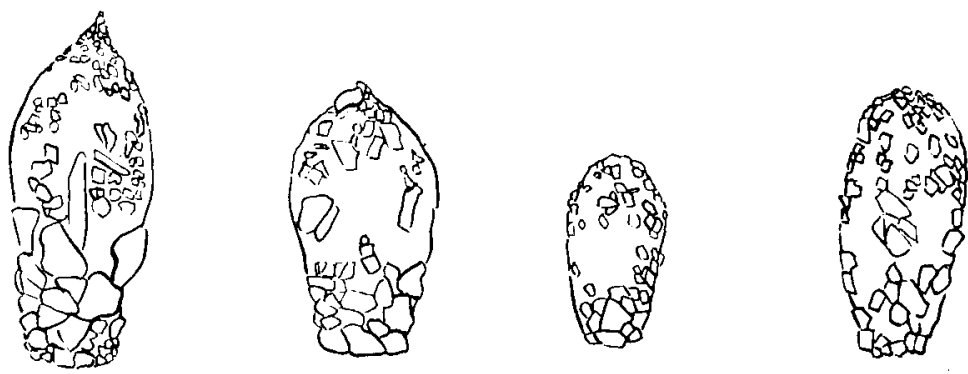

4.2

4.3

4.1

Plates 1-7 - The various morphotypes as enumerated in the list of morphotypes (p. 91-103) and identified by compound numbers. I = lateral view as drawn via camara lurida. Small sketches accompanying main figure indicate contours of lateral view schematically. General explanations see p. 90. Plate 1 - All types, with the exception of 3,3 , (3.3.1), 4.1 and 7.2, belong to the Fam. Difflugiidae. 1.1.1 - 1.3.1 and 3.3.1 see Plate 6 .

third diameter wouid appear as circular or compressed- elliptical (i.e. whether the third diameter is equal to, or smaller than, the second one).) $\mathrm{Dm}=$ diameter; ps $=$ pseudostome (longest diameter); $\mathrm{pp}=$ width of the pseudopodia.

\section{LIST OF MORPHOTYPES}

1.1.1. $\sim 300 \times 250 \mu \mathrm{m}, \mathrm{CS}$ compressed; construction of test smooth with tightly fitted silica plates. Pseudopodia of difflugia- type with large crystals (5). Difflugia spec, Fam. Difflugiidae Awerintzen 1906 (Decloitre 404). PI. 6.

1.1.2. $\sim 250 \times 220 \mu \mathrm{m}, \quad C S$ compressed; general form triangular or faintly heart- shaped, smooth construction with tightly fitted silica plates. Pp $\sim 15-20 \mu \mathrm{m}$, with large crystals (6); ingests fungus spores (2). Difflugia spec. PI. 6.

1.1. $(290-340) \times(210-250) \mu \mathrm{m} ; \mathrm{CS}$ compressed; test of coarse construction with large sand grains. Pp $\sim 15-20 \mu \mathrm{m}$, without crystals (3). Difflugia sp. Pl. 6.

1.2. $(220-290) \times(175-220) \mu \mathrm{m}, \mathrm{CS}$ compressed; coarse construction with large sand grains. $\mathrm{Pp} \sim 15-20$ $\mu \mathrm{m}$, without crystals (12); ingests fungus spores (4). Difflugia sp., probably same species as type 1.1. PI. 6.

1.2.1. $\sim 250 \times 180 \mu \mathrm{m}$, CS compressed; more or less smooth construction 
with silica plates. Pp $\sim 15-20 \mu \mathrm{m}$, with few large crystals (4). Difflugia sp. Pl. 6.

1.3. $\sim 220 \times 140 \mu \mathrm{m}, \mathrm{CS}$ more or less circular; coarse construction. Pp $\sim 15 \mu \mathrm{m}$, wihout crystals (1). Difflugia $\mathrm{sp}$., perhaps same species as type 1.2. Pl. 6.

1.3.1. $(215-225) \times(110-150) \mu \mathrm{m}$, CS circular, smooth, compact construction wih silica plates; pseudopodia difflugia- like, with crystals (3): ingests fungus spores and hyphae (1). Difflugia sp. PI. 6.

1.4. $(170-200) \times(120-150) \mu \mathrm{m}, \mathrm{CS}$ compressed; coarse construction. Difflugia sp., near D. golemaskyi Vuzetich, reported from Argentina (Decloitre 404).

1.5. $\sim 200 \times 100 \mu \mathrm{m}, \mathrm{CS}$ circular; construction variable, more or less smooth or coarse. Pp $15 \mu \mathrm{m}$, with (3) or without (1) crystals. Probably heterogenous group, partly overlapping with type 2.3. Difflugia $\mathrm{sp}$.

1.6. $(130-145) \times 120 \mu \mathrm{m}$, CS circular. Fam Difflugiidae (?).

2.1. $(150-190) \times 100 \mu \mathrm{m}, \mathrm{CS}$ of neck circular, of body somewhat compressed. Shape conspicuously asymmetrical, \pm coarse construction. Pp $\sim 12 \mu \mathrm{m}$, plasma without crystals (6). Difflugia sp., near D. compressa (Leidy) Gauthier- Lievre- Thomas var. loeffleri Laminger, reported from Mexico (Decloitre 404).

2.2. $(150-190) \times(90-125) \mu \mathrm{m}, \mathrm{CS}$ circular; test not conspicuously asymmetrical. \pm coarse construction except for neck. Pp $\sim 12 \mu \mathrm{m}$, without crystals (5). Difflugia sp.

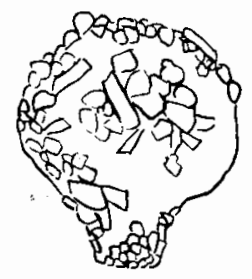

5.1

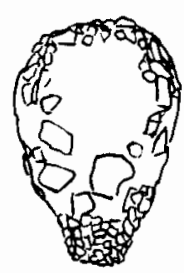

5.2

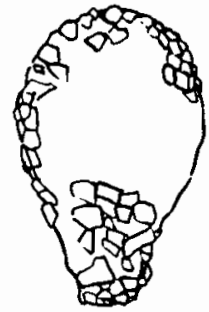

5.3

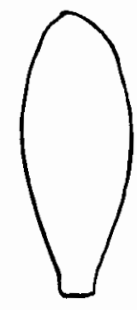

5.3 .1

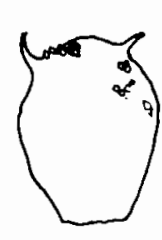

5.6 .1

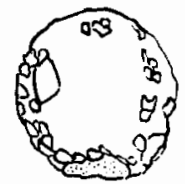

7.4

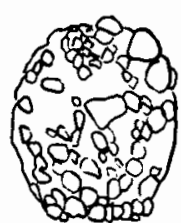

7.5

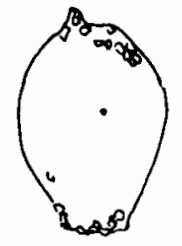

5.7

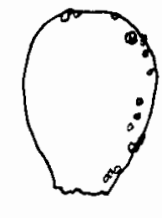

5.7

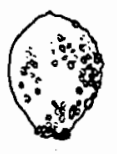

5.5

5.8

6.1

6.2

6.3

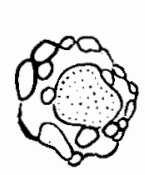

7.9

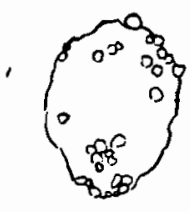

7.10

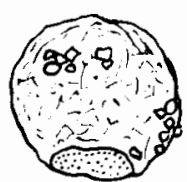

7.11

Plate 2 - Types 5.4 and $7.1-7.3$ see Plate 6 ; types $7.14,7.18$ and 7.19 see Plate7. 


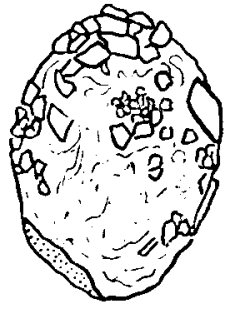

7.13

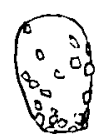

7.15

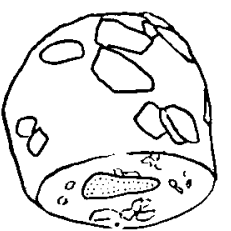

8.5 .2

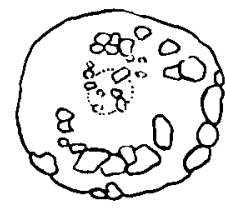

8.2 .2
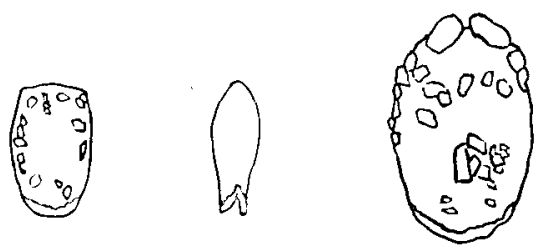

7.20

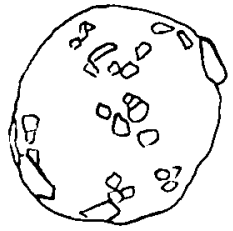

8.2 .1
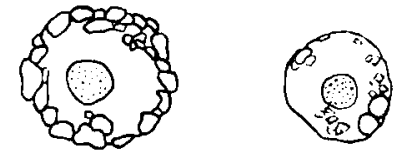

8.5

7.21

8.2 .1 .1
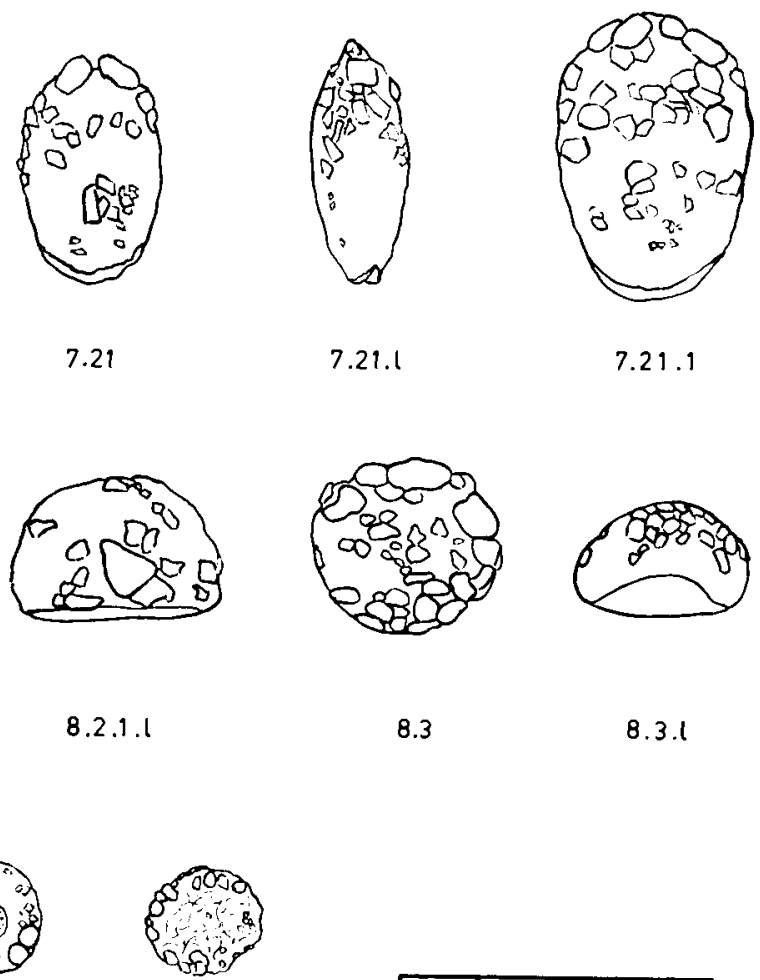

8.4

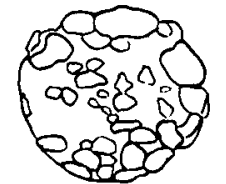

8.3

8.3 .1

Plate 3 - Types 8.1 and 8.2 see Plate 6 .

2.3. Uncertain group, intermediate between types 2.2. and 1.5. Difflugia $\mathrm{sp}$.

3.1. $(100-140) \times(60-85) \mu \mathrm{m}, \mathrm{CS}$ circular; coarse construction, usually with $1-2$ very large sand grains. Pseudopodia of difflugia - type, without crystals (4). Difflugia sp., near $D$. healy Laminger, (Decloitre 404).

3.2. $\sim 100 \times 70 \mu \mathrm{m}, \mathrm{CS}$ circular; probably same species as type 3.1 . but somewhat smaller and the exceptionally large sand grains are absent. Difflugia sp.

3.2.1. $\sim 75 \times(40-45) \mu \mathrm{m}$, CS circular; relatively coarse construction. Difflugia sp (?).

3.3. $\sim 100 \times 100 \mu \mathrm{m}$, globular; test irregular with wide range of grain size, usually with few very large sand grains. Pseudopodia numerous, filamentous and pointed, plasma granulated (3).

Sub- Class Granuloreticulosa (?), (see types 3.3.1., 4.1. and 7.12).

3.3.1. As types 3.3, but much larger species, Dm $\sim 170 \mu \mathrm{m}$. Sub- Class Granuloreticulosa (?), (see also types 4.1 and 7.12 )

3.4. $\sim 100 \times 50 \mu \mathrm{m}, \quad$ CS circular; \pm smooth construction with silica plates and sand grains. Pseudopodia difflugia-like, without crystals (1). Difflugia sp.

3.4.1. As type 3.4, but usually with 2, exceptionally with 3 , apical horns. Difflugia sp.

4.1. $(170-200) \times(65-90) \mu \mathrm{m}, \mathrm{CS}$ circular; test of very small silica platelets, appearing silverywhite under low- power microscope. 
Pseudopodia numerous, filamentous, anastomosing, with intense streaming of granular plasma, and with numerous, small vacuoles (6); apparently ingests bacteria (1). SubClass Granuloreticulosa (?), (see types $3.3,3.3 .1$ and 7.12 ).

4.2. $(200-290) \times(80-100) \mu \mathrm{m}$. CS circular; lower part of test with \pm coarse sand, upper part with, small silica platelets. Apical point usually pronounced, but sometimes absent. Pseudopodia difflugia- like, $15-20$ $\mu \mathrm{m}$, plasma granular, without large crystals (16). Ingests fungus hyphae and spores (5) and small thecamoe. bae (Cryptodiffugiaceae ?) (1). Difflugia $\mathrm{sp}$. near $D$. protoeiformis Lamarck (Moore 1978).

4.3. $(120-140) \times(50-70) \mu \mathrm{m}, \mathrm{CS}$ circular; test of smooth construction with fine silica plates. Pseudopodia difflugia- like, without crystals (2). Difflugia sp (?).

5.1. $(150-180) \times(120-170) \mu \mathrm{m}, \mathrm{CS}$ strongly compressed; test varies from coarse to smooth construction. $\mathrm{Pp} \sim 15 \mu \mathrm{m}$, without crystals (29); plasma within test densly packed with ovoid bodies ( $\sim 3 \mu \mathrm{m}$ long) which, when animal is crushed, are avidly ingested by Paramaecium sp. Ingests hyphae and spores of fungi (2) and tissue of unidentified decaying fruit (1). Difflugia $\mathrm{sp}$. near D. compressa var. africana Gauthier- Lievre- Thomas, (Decloitre 404).

5.2. $(150-200) \times 100 \mu \mathrm{m}$, circular; construction smooth, mostly with silica plates. Pseudopodia difflugia- like, with large crystals (8). Difflugia sp.

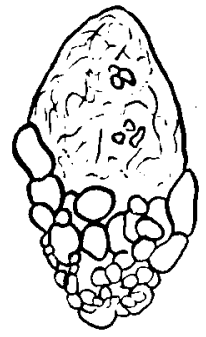

9.41

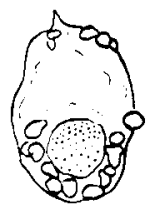

9.3 .1

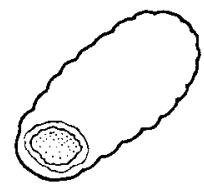

10.12

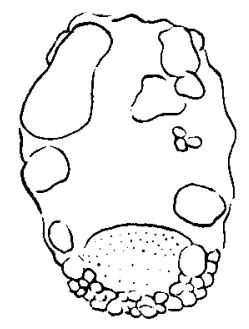

9.4

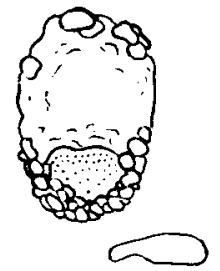

9.2
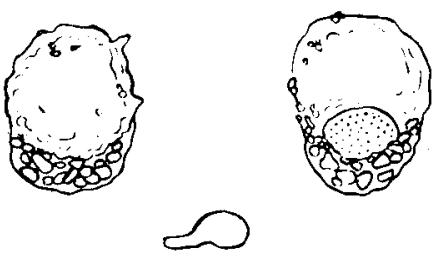

9.3
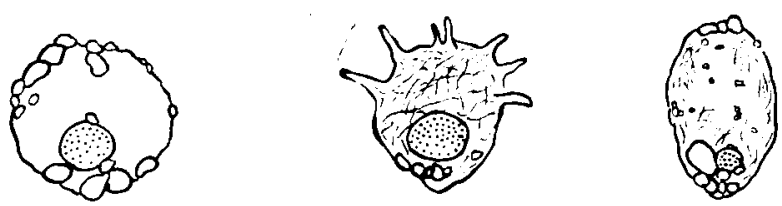

9.5 .1

9.6

9.8
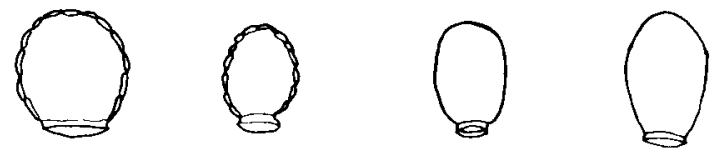

10.9 .3

10.10 .3

10.13

$200 \mu \mathrm{m}$

Plate 4 - Type 9.1 see Plate 6; Type 9.9 and further Euglyphidae see Plate 7. 


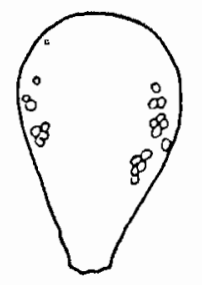

10.1

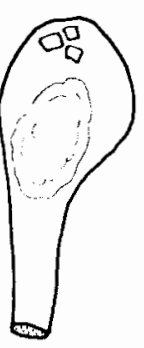

10.2

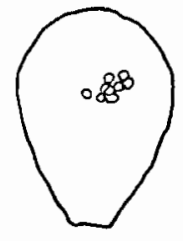

10.1

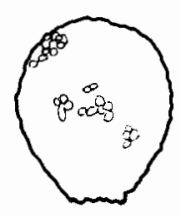

10.1 .1

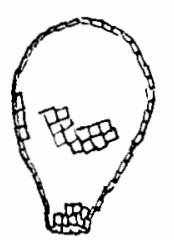

10.24.1

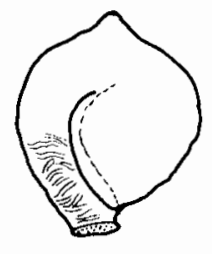

10.23

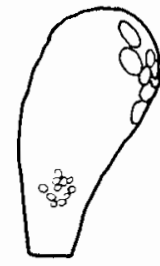

10.2 .1
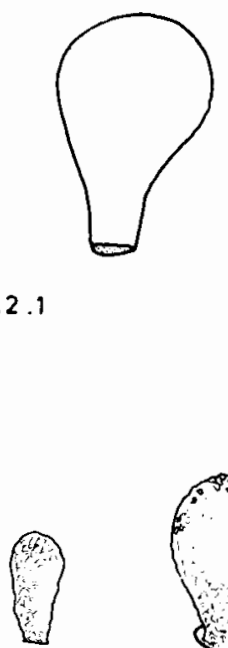

10.17

10.7

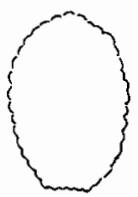

10.9
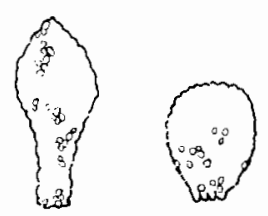

10.5
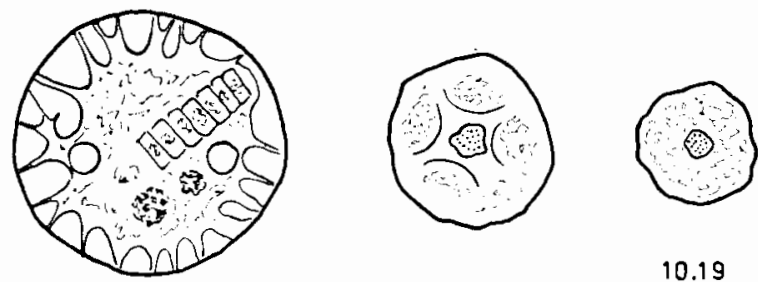

10.19
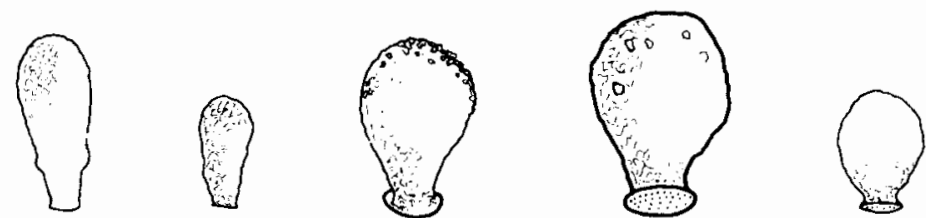

10.4

10.7 .1

10.7. 2

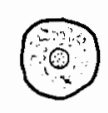

10.20

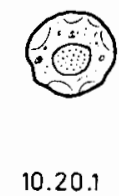

$200 \mu \mathrm{m}$

Plate 5 - Further Nebeliidae/Hyalospheniidae sce Plate 7.

5.2.1. $250 \times 120 \mu \mathrm{m}$, CS circular, PS 25 $\mu \mathrm{m}$; shape elongated- ovoid, construction smooth with silica plates. Fam. Difflugiidae (?).

5.3. $(180-200) \times(110-140) \mu \mathrm{m}, \mathrm{CS}$ compressed; construction smooth with tightly fitted silica platelets. Pp 15 - $20 \mu \mathrm{m}$, with crystals (28), (one observation without crysta!s type 5.1?). Ingests fungus spores (2). Difflugia sp., near $D$. lingula Penard var. Gauthier- Lièvre- Thomas, (Decloitre 404).

5.4. $(250-270) \times(150-170) \mu \mathrm{m}, \mathrm{CS}$ strongly compressed; smooth construction with fine silica platelets. Pseudopodia difflugia- like, $\sim 20 \mu \mathrm{m}$, with crystals (2). Ingests fungus spores (1 amaeba with 5 spores) and diatoms (1). Difflugia sp., near
D. lingula Penard, (Decloitre 404). PI. 6 .

$5.5 \sim 70 \times 50 \mu \mathrm{m}$, CS compressed; test of fine, round sand grains. Difflugia sp., near $D$. elliptica Carter, (Decloitre 404).

5.6. $120 \times 95 \mu \mathrm{m}, \mathrm{CS}$ strongly compressed; test $\pm^{\circ}$ chitinous with minute sand grains; usually lateral, apical horns. (Difflugia sp., near D. concava Wang- Nie from China, Decloitre 404, ?); more likely: Fam. Nebeliidae (Decloitre 404) or Hyaloshpeniidae, (Moore 1978).

5.7. As type 5.6, but without, or with a single, median apical horn; possibly same species.

5.8. $70 \times 50 \mu \mathrm{m}, \mathrm{CS}$ strongly compressed, test a mixture of chitinous secretion and finest sand grains. Fam. Nebe- 
liidae Taranek 1862, Nebela sp. (?) near $N$. kundulungui Van Oye, (Decloitre 404). (Other Nebeliidae see types $10.1-10.5,10.23,10.24)$.

6.1. $(130-140) \times(50-70) \mu \mathrm{m}, \mathrm{CS}$ circular; test of chitinous secretation with mostly silica plates. Fam. Difflugiidae (?).

6.2. $(120-130) \times(35-50) \mu \mathrm{m}, \mathrm{CS}$ circular; test of slightly irregular flask shape, composed of chitinous secretation, in parts finest sand particles. Fam. Difflugiidae (?), near $D$. nebeloide Gauthier- Lievre- Thomas from Congo (Decloitre 404).

6.3. $\sim 80 \times 30 \mu \mathrm{m}$. As type 6.2 , but a distinctly smaller species. Difflugia $\mathrm{sp}$ (?), near $D$. nebeloide.

7.1. \pm globular, Dm $200-230 \mu \mathrm{m}$, ps $100-130 \mu \mathrm{m}$. Coarse sand. Difflugia sp., near D. corona Wallich var. ecornis Gauthier- Lievre- Thomas megastoma Laminger (Decloitre 404). Certainly a different species from $D$. corona Wallich, (Decloitre 404) which also occurs in the region of Manaus (Lago Samauma, Ilhas das Anavilhanas). Pl. 6.

7.2. \pm globular, Dm $180-200 \mu \mathrm{m}$; test of chitinous secretion and sand with $1-2$ thin, small chitinous horns. PI. 6.

Fam. Centropyxiidae De Flandre 1953, Centropyxis sp., near C. ovoidea Decloitre from Venezuela, (Decloitre 404; other Centropyxiidae see types 8 . and 9$)$.

7.3. $(180-190) \times(150-180) \mu \mathrm{m}, \mathrm{CS}$ circular; test of smooth construction with silica plates. Fam. Difflugiidae, Difflugia sp (?). PI. 6 .

7.4. $\sim 100 \times 110 \mu \mathrm{m}$, CS circular; test chitinous with finest sand and silica platelets. Fam. Difflugiidae (?).

7.5. $(110-140) \times(100-110) \mu \mathrm{m}, \mathrm{CS}$ circular; test of relatively coarse sand. $\mathrm{Pp} \sim 12 \mu \mathrm{m}$, of difflugia- type, without crystals (35). Ingests fungal hyphae and spores (6) and small arcellids (2). Difflugia sp., near $D$. minuta Rampi, (Decloitre 404).

7.6. $150 \times 100 \mu \mathrm{m}, \quad$ CS circular; ovoid test of smooth construction with silica plates. Difflugia sp (?).

7.7 $\quad(120-130) \times(70-80) \mu \mathrm{m}$. CS circular; test mostly of silica plates, often with large, apical sand grain. $\mathrm{Pp}$ of difflugia- type, without crystals (2). Difflugia sp (?)

7.8. $90 \times 80 \mu \mathrm{m}, \mathrm{CS}$ circular; test of mostly roundish sand grains; overlapping with type 7.5 and perhaps same species. Difflugia $\mathrm{sp}$.

7.9. \pm globular test of coarse sand, $\mathrm{Dm} \sim 70 \mu \mathrm{m}$. Single occurrence of uncertain type. Fam. Difflugiidae (?).

7.10. $\sim 100 \times 80 \mu \mathrm{m}, \mathrm{CS}$ circular; test irregular ovoid shape, of densely packed, finest sand. Fam. Difflugiidae (?) or Gromiidae (?).

7.11. \pm globular, $\mathrm{Dm} 100-110 \mu \mathrm{m}$, test parchment- like and of somewhat irregular shape, with small silica platelets. Fam. Gromiidae (?), (Moore, 1978).

7.11.1. As type 7.11, but a distinctly smaller species, Dm $80-95 \mu \mathrm{m}$. Fam. Gromiidae (?), (Moore, 1978).

7.12. $(130-140) \times(70-80) \mu \mathrm{m}, \mathrm{CS} \pm$ circular; shape of test irregular; composed of finest silica platelets, appearance under low- power microscope silvery- white. Pseudopodia numerous, filamentous, granular, with anastomoses. Animal in every aspect similar to type 4.1 , except for size. (see types 3.3 and 33.1 ). Sub- Class Granuloreticulosa (?), (Moore, 1978). PI. 1.

7.13. $(170-190) \times(130-140) \mu \mathrm{m}, \mathrm{CS}$ \pm circular; shape irregular- ovoid, pseudostome displaced laterally. Test of parchment- like exretion with small, scattered silica p'ate'ets, specially on apical side. Fam. Gromilidae, (Moore, 1978). 


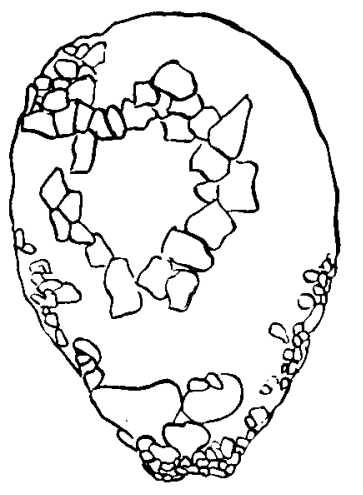

1.1 .1

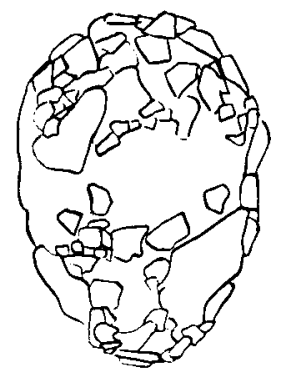

1.2 .1

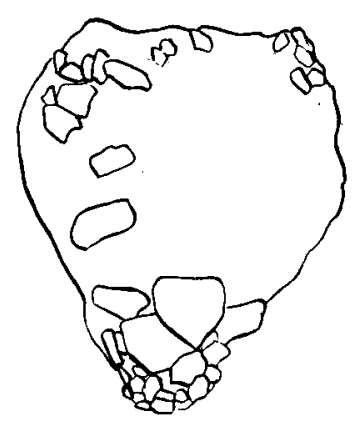

1.1.2

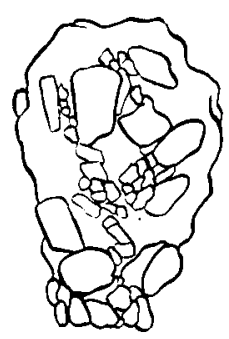

1.3

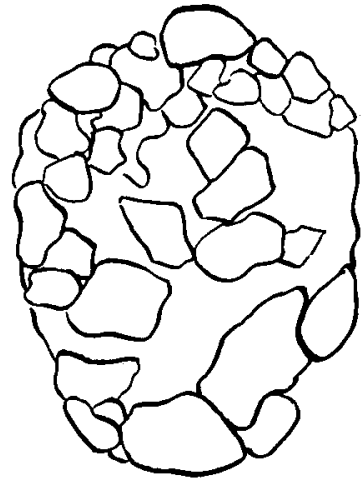

1.1

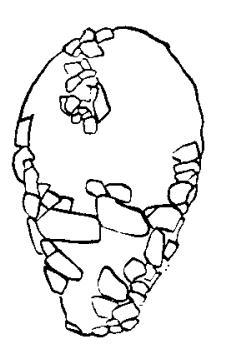

1.3.1

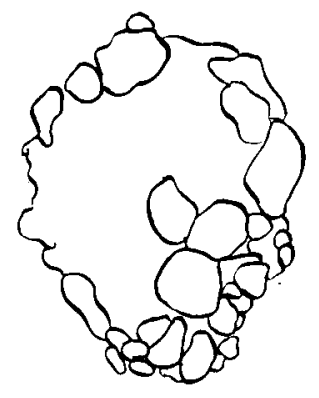

1.2

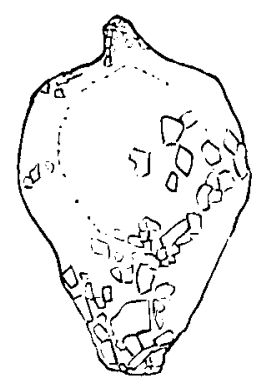

5.4

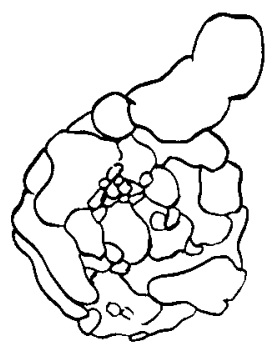

3.3.1

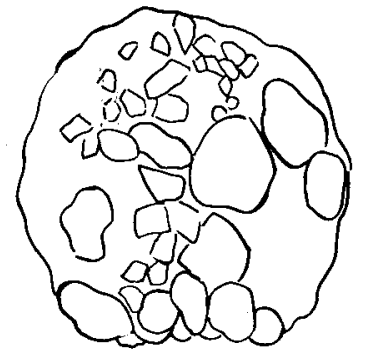

7.1

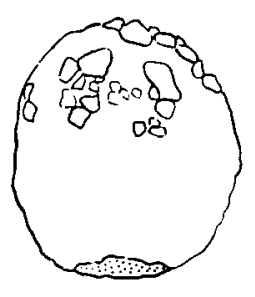

7.3

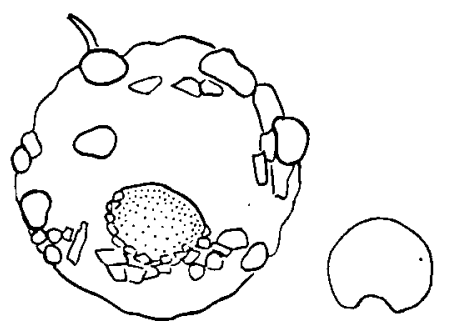

7.2

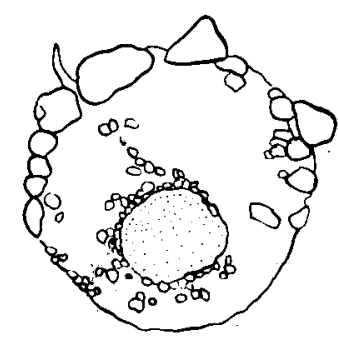

9.1

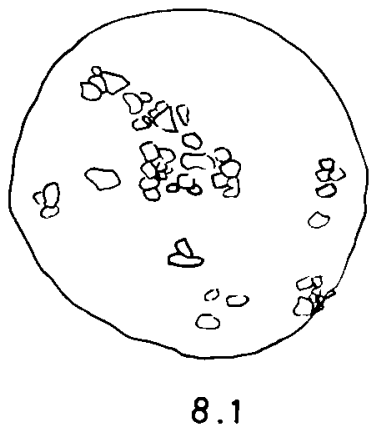

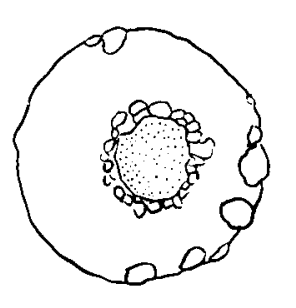

8.2

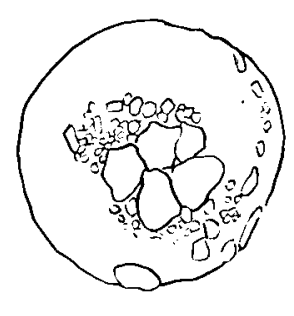

8.2

Plate 6 - Large forms; figures reduced as compared to Plates 1-5.

The thecamoebae... 
7.14. \pm globular, $\mathrm{Dm} 50-60 \mu \mathrm{m}$; test chitinous with smallest, scattered silica platelets. Fam. Gromiidae, (Moore, 1978), or near Oopyxis cophostoma Jung (?), (Decloitre 404). PI. 7.

7.15. $(70-80) \times(40-50) \mu \mathrm{m}, \mathrm{CS}$ circular; test of compact construction with small silica platelets. Pseudopodia difflugia- like without crystals (1). Difflugia sp. (?), near D. penardi Hopkinson from Venezuela, (Decloitre 404).

7.16. $(70-75) \times(35-40) \mu \mathrm{m}$, CS circular; wrinkled, chitinous test, pseudostome lined with ring of sand grains. Fam. Hyalospheniidae $=$ (?) Nebeliidae, (Decloitre 404). Jungia sp., (Moore, 1978; Decloitre 404). PI. 7. (Nebeliidae see also types 5.8; $7.19-7.21 ; 10.1-10.5 ; 10.23,10.24)$.

7.17. $\sim 50 \times 25 \mu \mathrm{m}, \mathrm{CS}$ circular; test of smallest sand particles. Very similar to type 7.18 , but somewhat more slender and apical sand grains smaller. Fam. Difflugiidae (?).

7.18. $\sim 45 \times 30 \mu \mathrm{m}$, CS circular; test of small silica plates. Fam. Difflugiidae (?) PI. 7.

7.19. $(85-95) \times \sim 50 \mu \mathrm{m}$, CS circular to slightly compressed; chitinous test with silica platelets. Pseudostome with re-enforced chitinous ring. Fam. Hyalospheniidae, Heleopera sp., (Moore, 1978). PI. 7.

7.20. $(85-90) \times \sim 50 \mu \mathrm{m}, \quad$ CS strongly compressed; lateral view of pseudostome triangular, otherwise similar to type 7.19. Heleopera sp., (Moore, 1978).

7.21. $\sim 150 \times 90 \times 50 \mu \mathrm{m}, \mathrm{CS}$ compressed; chitinous test with silica platelets; pseudostome with re-enforced chitinous ring. Heleopera sp., (Moore, 1978).

7.21.1. As type 7.21, but distinctly larger species: $(180-190) \times(130-140)$ um. Heleopera sp., (Moore, 1978).
8.1. Disk- shape, $\mathrm{Dm} \sim 250 \mu \mathrm{m}$; chitinous test with finest sand grains. Fam. Centropyxiidae De Flandre 1953, (Decloitre 404), or Fam. Trigonopyxidae, (Moore, 1978); Cyclopyxis sp. (?). Pl. 6.

8.2. Disk- shape, Dm $180-200 \mu \mathrm{m}$, ps $\sim 40 \mu \mathrm{m} \mathrm{Dm;} \mathrm{test} \mathrm{mostly} \mathrm{of} \mathrm{small}$ silica plates. Fam. Centropyxiidae, (Decloitre 404), or Fam. Trigonopyxidae, (Moore, 1978); Cyclopyxis sp., near $C$. intermedia (Kupferath) Decloitre from Congo, (Decloitre 404). PI. 6.

8.2.1. Semiglobular, Dm $130-140 \mu \mathrm{m}$; test of silica plates. Cyclopyxis $\mathrm{sp}$.

8.2.2. Disk- shape, $\mathrm{Dm} \sim 125 \mu \mathrm{m}$; test of sand and silica plates. Cylopyxis sp (?).

8.3. $D \mathrm{~m} 100-125 \mu \mathrm{m}$, hight $\sim 70 \mu \mathrm{m}$; test chitinous secretion and sand, peripheral particles larger. Cyclopyxis sp., near C. maynei (Kupferath) Decloitre from Congo, (Decloitre 404).

8.3.1. Disk- shape, $\mathrm{Dm} \sim 100 \mu \mathrm{m}$, without visible pseudostomal field. Fam. Phryganellidae (?), (Moore, 1978).

8.4. Disk- chape, Dm $65-70 \mu \mathrm{m}$, without visible pseudostomal field; composed of smallest sand particles. Fam. Phryganellidae, Phryganella sp. (?) (Decloitre 404).

8.5. Semiglobular, Dm $85-90 \mu \mathrm{m}$, ps $\sim 35 \mu \mathrm{m}$; chitinous test with sand. Fam. Trigonopyxidae (Moore, 1978) or Fam. Centropyxiidae (Decioitre 404); Cyclopyxis sp.

8.5.1. Similar to type 8.5, but smaller; $\mathrm{Dm}$ $50-70 \mu \mathrm{m}$, ps $\sim 20 \mu \mathrm{m}$. Cyclopyxis sp.

8.5.2. $\mathrm{Dm} \sim 110 \mu \mathrm{m}$, hight $\sim 125 \mu \mathrm{m}$, ps $\sim 45 \mu \mathrm{m}$; pseudostomal field plane, with much smaller particles. Cyclopyxis sp. (?).

8.6. Similar to type 8.4 , but smaller, Dm $\sim 50 \mu \mathrm{m}$. Fam. Phryganellidae (?). 


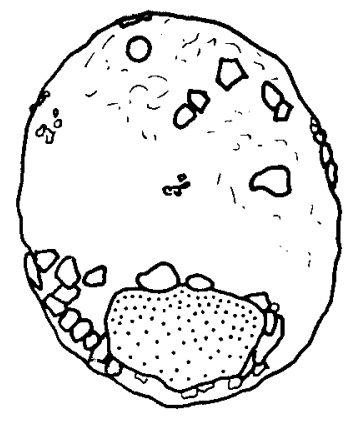

7.14

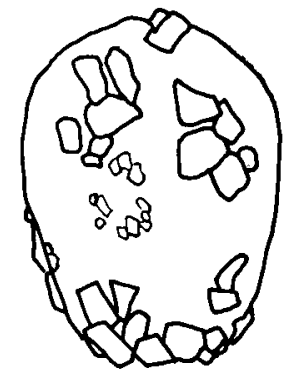

7.18

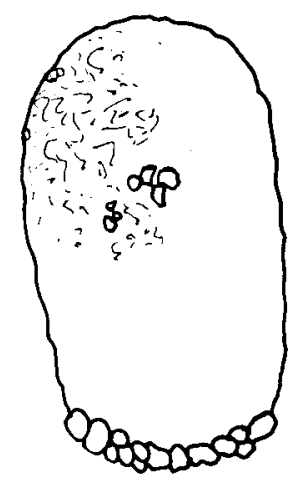

7.16

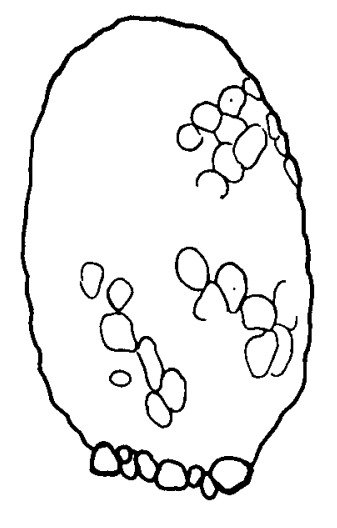

10.11

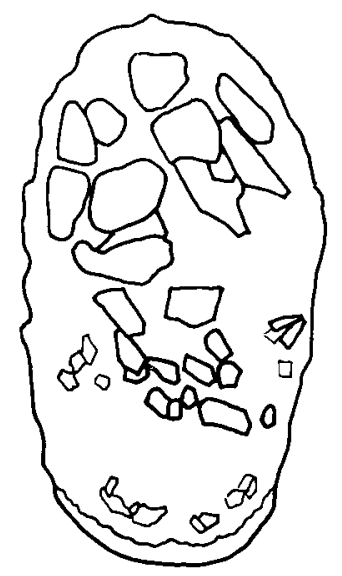

7.19

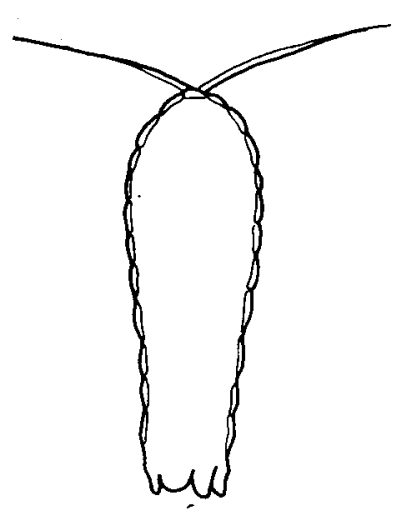

10.8

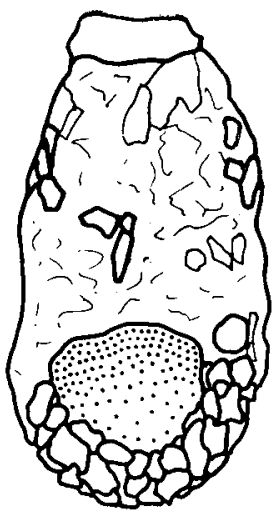

9.9

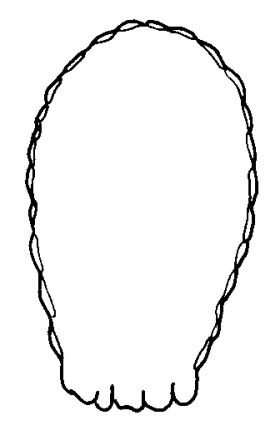

10.6
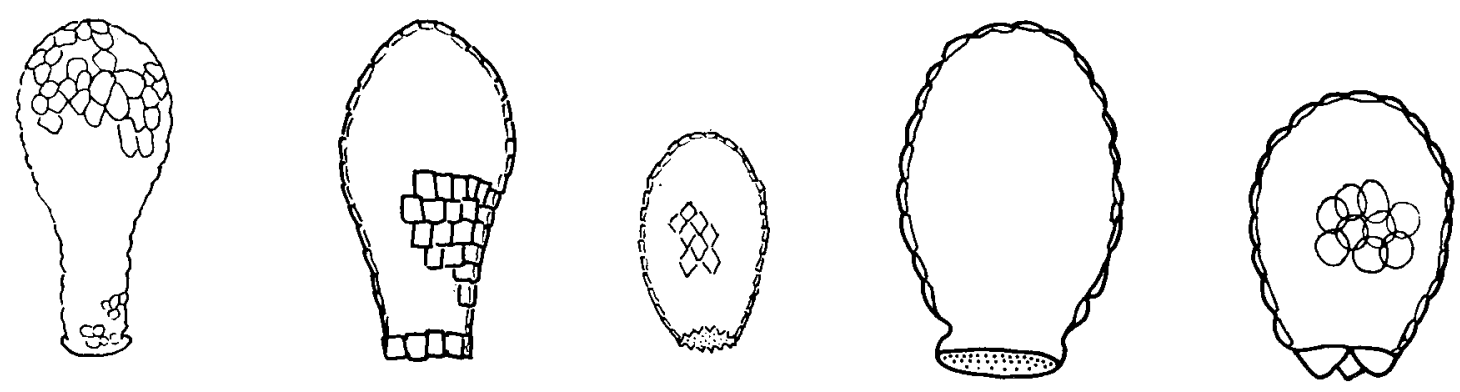

10.4 .1

10.24

10.21

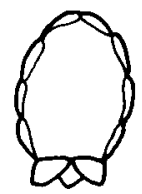

10.22

10.10 .1 
9.1. Disk- chape, Dm $\sim 200 \mu \mathrm{m}$, ps $70-$ $80 \mu \mathrm{m} \mathrm{Dm}$; chitinous test with $1-2$ small horns; coarse sand on dorsal side and finer grains on pseudostomal field, particularly on rim of pseudostome. Fam. Centropyxiidae (Decloitre 404, Moore, 1978), Centropyxis sp., near $C$. ecornis (Ehrenberg) Leidy, forma paradoxa Jung from Chile, (Decloitre 404; see also type 7.2.). PI. 6.

9.2. $(120-130) \times(80-90) \mu \mathrm{m}, \mathrm{CS}$ compressed, ps $45-50 \mathrm{um}$ Dm; chitinous test dorsally coverd with sand, ventrally with less and finer particles. Conspicuous ring of smaller sand grains on rim of pseudostome, not embedded in hyaline secretion. Fam. Centropyxidae.

9.3. $(110-120) \times(80-90) \mu \mathrm{m}$, ps $40-50 \mu \mathrm{m} \mathrm{Dm}, \mathrm{CS}$ less compressed than in type 9.2; chitinous test with occasional small, apical tubercules and scattered sand grains; distal rim of pseudostome lined with smaller sand grains, conspicuously embedded in hyaline secretion. Fam. Centropyxidae; Centropyxis sp., near C. ventricosa Bartos from Java (Decloitre 404).

9.3.1. $\quad(95-110) \times(65-80) \mu \mathrm{m}$, ps $25-$ $35 \mu \mathrm{m}$; CS compressed; very similar to type 9.3 , but somewhat irregular in shape and a strong tendency to form apical horns and tubercules. Single, broad pseudopodium with irregular small crystals (1). Centropyxis sp, near $C$. piriformis van Oye from Congo (Decloitre 404; as both types, 9.3. and 9.3.1, occur in the same streams, they might be a single, but variable species).

9.3.2. $(70-80) \times(40-55) \mu \mathrm{m}$, ps $\sim 25$ $\mathrm{Dm}, \mathrm{CS}$ compressed; construction of test as type 9.3 and 9.3 .1 , but no apical tubercules and a strong tendency to glue several large grains to the apex. Pseudopods: broad "foot" with $3-5$ pointed, short "toes", plasma without crystals (1). Centropyxis sp., (see also type 9.9).

9.3.3. $(60-70) \times(30-35) \mu \mathrm{m}$, ps $\sim 20$ $\mu \mathrm{m}$ Dm, CS only slightly compressed; construction of test as in type 9.3.2, but sand rim around pseudostome only occasionally well developed, (see also type 9.7). Centropyxis sp. (Although range of sizes slightly overlapping with type 9.3.2, this type is of a distinctly smaller size class).

9.4. $(150-210) \times(100-160) \mu \mathrm{m}$, ps $(60-70) \times(25-40) \mu \mathrm{m}, \mathrm{CS}$ compressed, sometimes strongly so; chitinous test with coarse apical sand, more or less densly set, and dense ring of smaller grains around pseudostome. Very variable group, also within same stream. Centropyxis sp., near C. marsupiformis (Wallich) Deflandre var ecornis van Oye from Java, (Decloitre 404).

9.5. $(80-95) \times(65-75) \mu \mathrm{m}$; ps circular, $25 \mu \mathrm{m} \mathrm{Dm}$; CS strongly compressed; parchment- like test with smallest sand particles. Fam. Plagiopyxidae Bonnet- Thomas or Fam. Centropyxidae (?) (Decloitre 404).

9.5.1. Disk- shape, Dm $95-100 \mu \mathrm{m}$, pseudostome circular, Dm $25-35 \mu \mathrm{m}$; dorsally covered with silica platelets, ventral pseudostomal field chitinous with smaller silica particles. Fam. Centropyxidae (?).

9.6. $(90-120) \times(75-100) \mu \mathrm{m}, \mathrm{CS}$ strongiy compressed; ps $35-50$ $\mu \mathrm{m}$ Dm; chitinous test, variable in form, with several apical horns and few, scattered sand grains. $5-6$ narrow pseudopodia with rounded tip, without crystals (1). Centropy$x$ is sp., near $C$. notonyx (Jung) from Chile and North Africa, (Decloitre 404).

9.7. Similar to type 9.3.3, but without large apical sand grains; ring of small sand grains around pseudos- 
tome well developed, perhaps same species. Centropyxis sp.

9.8. $(105-110) \times(55-65) \mu \mathrm{m}, \mathrm{CS}$ almost circular; ps $15-20 \mu \mathrm{m} \mathrm{Dm}$; test chitinous with silica platelets. Fam. Centropyxidae (?).

9.9. (75 - 95) $\times(45-55) \mu \mathrm{m}, \mathrm{CS}$ compressed, ps $\sim 50 \mu \mathrm{m} \mathrm{Dm}$; chitinous test with few larger, generally apical sand grains and with conspicuous ring of densly packed, small grains around outer rim of pseudostome. Still, separation from type 9.3.2 and 9.7 is doubtful. Centropyxis sp. PI. 7.

10.1. $(140-200) \times(100-130) \times \pm 35$ $\mu \mathrm{m}$; transparent, colourless test with pattern of round scales. Psejdopodia difflugia- like without crystals $(\infty)$; ingests diatoms (3), fungus spores and hyhae (11). Fam. Hyalospheniidae (Moore, 1978) or Nebeliidae (Decoitre 404). Nebela sp., N. collaris Ehrenberg (Moore, 1978) or $N$. barbata Leidy from Chile (Decloitre 404).

10.1.1. $(120-130) \times 100 \mu \mathrm{m}$, ps $45-50$ $\mu \mathrm{m}, \quad$ CS compressed; structrure of test as in type 10.1. Nebela sp.

10.2. $220 \times 80 \mu \mathrm{m}$, ps $\sim 22 \mu \mathrm{m}$ Dm, CS circular; \pm asymetrical flask, test transparent with few scattered square plates (in live condition). Fam. Hyalospheniidae/Nebeliidae. Quadrulella sp., Q. tubulata Gauthier- Lievre, (Decloitre 404). (The symmetrical form, uniformely covered with a pattern of square scales, was also found, in Rio Tarumã-Mirim, but is no part of the quantitative series; see also types 10.24. and 10.24.1).

10.2.1. $160 \times 100 \times 70 \mu \mathrm{m}$, ps $25 \mu \mathrm{m}$; transparent test with pattern of round scales. Fam. Hyalospheniidae/Nebeliidae, Nebela sp, near N. longicollus Penard, (Moore, 1978).

10.3. $(110-125) \times(45-50) \mu \mathrm{m}$, ps $\sim 25$ $\mu \mathrm{m}, \mathrm{CS}$ circular; transparent flask of \pm irregular shape with pattern of irregular, rounded scales. Pseudopodia of difflugia- type, without crystals (3), oblong- quadrangular crystals in central plasma (1); ingests fungus spores and hyphae (3). Nebela sp, near $N$. digitiformis Vucetich from Argentina (Decloitre 404)

10.4. $120 \times 150 \mu \mathrm{m}$, ps $\sim 20 \mu \mathrm{m}$, CS circular; transparent test with faint marble pattern. Fam. Hyalospheniidae/ Nebeliidae, probab̆ly Certesella sp., (Moore, 1978).

10.4.1. $\quad(70-75 \times(28-40) \mu \mathrm{m}$, ps $\sim 20$ $\mu \mathrm{m}$, CS circular; transparent test with pattern of round scales; very similar to type 10.3, but without apical point. Ingests fungus hyphae (2). Nebela sp. PI. 7.

10.4.2. $65 \times 25 \mu \mathrm{m}$, ps $\sim 15 \mu \mathrm{m}$ Dm, CS circular; flask with faint marble pattern. Fam. Hyalospheniidae/Nebeliidae.

10.4.3. Minuscule flask (maximal length $\sim 35 \mu \mathrm{m}$ ); no accurate record. Fam. Cryptodifflugiaceae $(? ; ;$ see also $10.13-10.15$ ).

10.5. $(75-80) \times(50-60) \mu \mathrm{m}$, ps $\sim 20$ $\mu \mathrm{m}$, CS compressed; transparent test with pattern of irregular, roundish scales. Ingests fungus hyphae and spores (3). Nebela sp, near N. pusilla Vucetich from Argen. tina, (Decloitre 404 (6)).

10.6. $(45-55) \times(25-30) \mu \mathrm{m}$, ps $\sim 20$ $\mu \mathrm{m}, \mathrm{CS}$ circular; transparent test with pattern of round scales. Fam. Euglyphidae Wailes 1919, (Moore, 1978 and Decloitre 404); Euglypha sp. PI. 7 .

10.7. (115 - 125) $\times 70 \mu \mathrm{m}$, CS circular; shape of amphora, test chitinous, not transparent, with smallest sand particles.

Fam. Gromiidae, Lagunculina sp. (Moore, 1978), or Fam Nebeliidae, Psychochila sp., near $P$. cratera 
(Wailes) Jung from Congo and Canada (Decloitre 404); (see also types $7.11,7.13$ ).

10.7.1. $140 \times 90 \mu \mathrm{m}, \mathrm{CS}$ circular; except for size exactly as type 10.7. Lagunculina $\mathrm{sp}$, or Psychochila sp.

10.7.2. $75 \times 50 \mu \mathrm{m}, \mathrm{CS}$ circular, pseudostome with collar, $\sim 30 \mu \mathrm{m} \mathrm{Dm}$; transparent test with faint marble pattern. Fam. Hyalospheniidae/Nebeliidae (?)

10.8. $70 \times 25 \mu \mathrm{m}, \mathrm{CS}$ circular; transparent test with pattern of round scales and 2 apical spines. Pseudopodia $3-6$, filamentous, pointed (1). Fam. Eugiyphidae, Euglypha sp, near $E$. cristata Leidy from Australia, but somewhat larger, (Decloitre 404). PI. 7.

10.8.1. $25 \times \sim 10 \mu \mathrm{m}$, CS circular; transparent test with several long, apical spines (no accurate record). Fam. Euglyphidae.

10.8.2. $115 \times 40 \mu \mathrm{m}, \mathrm{CS}$ circular; transparent test with pattern of round scales, which are distinctly smaller than in type 10.8 ; no apical spines. General shape as type 10.8. Euglypha sp. (?).

10.9. $115 \times 70 \mu \mathrm{m}$, CS circular; ovoid transparent test with pattern of circular scales. Fam. Hyalospheniidae/ Nebeliidae or Euglyphidae (?).

10.9.1. $95 \times 60 \mu \mathrm{m}, \mathrm{CS}$ circular; transparent test with rhomboid scales. Fam. Euglyphidae, near Tracheleuglypha dentata (Veidovsky), (Moore, 1978).

10.9.2. (85 - 90) $\times 60 \mu \mathrm{m}$, CS circular; transparent test with pattern of large, round scales. Euglypha sp., (Moore, 1978).

10.9.3. Globular shape, Dm $\sim 70 \mu \mathrm{m}$, transparent test with large, round scales and distinct collar. Sub- Fam. Euglyphinae, Sphenoderia sp., (Moore, 1978).

10.10. $(55-65) \times(25-35) \mu \mathrm{m}$, CS circular; transparent test with pattern of circular scales, distinct collar.
Ingests fungus hyphae (2). Sphenoderia sp., near $S$. foveosa Playfair, (Decloitre 404). PI. 7.

10.10.1. $\sim 30 \times 20 \mu \mathrm{m}, \mathrm{CS}$ circular; similar to type 10.10 , but test only $4 x$ the hight of a single scale. Sphenoderia sp. PI. 7.

10.10.2. $45 \times 30 \mu \mathrm{m}, \mathrm{CS}$ circular; as type 10.10 , but hight of test only $5-6 x$ size of single scale. Ingests fungus spores. Sphenoderia $\mathrm{sp}$.

10.10.3. $70 \times 50 \mu \mathrm{m}$, CS circular; as type 10.10, but disdinctly egg- chaped; total hight $6-7 \times$ size of single scale. Sphenoderia sp.

10.11. $75-50 \mu \mathrm{m}, \mathrm{CS}$ circular; transparent test with pattern or irregular, roundish scales, pseudostome lined with a row of sand grains. Fam. Hyalospheniidae/Nebeliidae, Jungia sp (?) PI. 7. (see type 7.16).

10.12. $(140-145) \times(55-70) \mu \mathrm{m}$, ps $25-30 \mu \mathrm{m}, \mathrm{CS}$ compressed; test in form of slipper, transparent and with a pattern of round scales. Pseudopodia numerous, filamentous and pointed; ingests fungus spores (1). Fam. Euglyphidae, Sub-Fam. Trinematinae, Trinema sp, (Moore, 1978 and Decloitre 404), near $T$. grandis Golemansky (Decloitre 1981).

10.12.1. $(80-100) \times(45-50) \mu \mathrm{m}, \mathrm{ps} \pm 20$ $\mu \mathrm{m}$. form and structure as type 10.12. Trinema sp.

10.12.2. $\sim 50 \times 25 \mu \mathrm{m}$, ps $\sim 12 \mu \mathrm{m}$, CS less compressed than former two types, but general structure similar. Trinema sp.

10.13 $\sim 70 \times 45 \mu \mathrm{m}$, CS circular; transparent egg- shaped test without any recognizable pattern, distinct collar. Fam. Cryptodifflugiaceae (?).

10.13.1. $85 \times 50 \mu \mathrm{m}$, ps $25 \mu \mathrm{m}$, CS circular; collar distinct, but narrow. Fam. Cryptodifflugiaceae [?].

10.14. $\sim 55 \times 35 \mu \mathrm{m}$, ps $\sim 20 \mu \mathrm{m}, \mathrm{CS}$ compressed; test in shape of slipper, but without recognizable pattern, 
uniformely transparent. No adequate drawings. Fam. Cryptodifflugiaceae (?), resembling Wailesella, (Moore, 1978).

10.15. $(30-35) \times \sim 20 \mu \mathrm{m}, \mathrm{CS} \pm$ circular. Similar to type 10.14; no adequate drawings. Fam. Cryptodifflugiaceae (?), resembling Wailesella sp (?) (Moore, 1978).

10.16. $\sim 70 \times 35 \mu \mathrm{m}, \mathrm{CS}$ compressed; general structure and shape as types 10.12 - 10.12.2. Trinema sp.

10.17. $(70-75) \times \sim 30 \mu \mathrm{m}$, CS circular, ps $\sim 18 \mu \mathrm{m}$; chitinous test with marble pattern; (see also types 10.4-). Fam. Hyalospheniidae/Nebeliidae (?).

10.18. $\sim 45 \times 25 \mu \mathrm{m}$, CS circular, ps $\sim 20$ $\mu \mathrm{m}$; test completely colour- and structure- less; bell- or difflugiashape. Fam. Cryptodifflugiaceae (?) (Moore, 1978). No adequate drawing)

10.18.1. $\sim 32 \times 20 \mu \mathrm{m}$, ps $\sim 18 \mu \mathrm{m}$, CS circular; test as type 10.18 , but smaller. Fam. Cryptodifflugiaceae (?).

In the avaliation of the quantitative data, the types 10.18 and 10.18.1. may comprize several species.

10.19. Disk- shape, $\mathrm{Dm} \pm 70 \mu \mathrm{m}$, ps $\sim 18$ $\mu \mathrm{m}, \mathrm{CS}$ estremely compressed; chitinous test, dark brown- groen, finely dotted. Ingests fungus spores (1). Fam. Arcellidae (Ểrenberg) Deflandre 1953, near Arcella infraterricola Chardez from Belgium, although much larger, (Decloitre 404 (7)).

10.19.1. Disk- shape, Dm $100-105$ !m, ps $\sim 20 \mu \mathrm{m}$; structure and colour of test as in type 10.19. Ingests fungus spores (1) and diatoms (1). Arcella $\mathrm{sp}$, near $A$. infraterricola (?)

10.20. Disk- shape, $\mathrm{Dm} \sim 50 \mu \mathrm{m}$, ps $\sim 10$ $\mu \mathrm{m}$; as type 10.19 , but smaller. Ar. cella sp, near $A$. infraterricola (?)

10.20.1. Disk- shape, $\mathrm{Dm} \sim 50 \mu \mathrm{m}$, ps $\sim 20$ $\mu \mathrm{m}$, chitinous test, light yellowtransparent. Arcella sp.
10.20.2. Disk- shape, $\mathrm{Dm} \sim 170 \mu \mathrm{m}$, chitinous test, light yellow- transparent. Ingests diatoms (1). Arcella sp.

10.21. $40 \times 23 \mu \mathrm{m}, \mathrm{CS}$ circular; transparent test with pattern of rhomboid scales. Fam. Euglyphidae, Sub-Fam. Euglyphinae, Euglypha sp. (?) (Moore, 1978; see also types 10.6, 10.8. and 10.9.2). Pi. 7.

10.22. $60 \times 40 \mu \mathrm{m}, \mathrm{CS}$ circular; ovoid, transparent test with large, round, overlapping scales; collar of 3 tringular, separate pieces. Sub-Fam. Euglyphinae, Sphenoderia sp. (?) (Moore, 1978; see also types 10.9.3; 10.10-). PI. 7.

10.23. $(130-150) \times(110-115) \mu \mathrm{m}$, ps $25-40 \mu \mathrm{m}$; helical test with vermiform pattern; pseudopodia diffugia- like, plasma' finely granulated. Fam. Hyalospheniidae/Nebeliidae, Lesquereusia sp, near L. gibbosa Gauthier- Lievre- Thomas from Venezuela, (Decloitre 404).

10.24. $\sim 58 \times 30 \mu \mathrm{m}$; CS circular; transparent test with quadratic scales. Fam. Hyalospheniidae/Nebeliidae. Quadrulella sp, PI. 7. (see also below and type 10.2; Moore, 1978).

10.24.1. (125 - 145) $\times(85-90) \mu \mathrm{m}, \mathrm{CS}$ compressed; transparent test with quadratic scales. Pseudopodia diffugia- like, finely granulated, without crystals. Ingests fungus hyphae (16) and yeast (in the laboratory). Quadrulella $\mathrm{sp}$ (see also above and type 10.2). PI. 7.

\section{OBSERVATIONS PERTINENT TO THE LIST OF}

\section{MORPHOTYPES}

Within the larger, more or less flask- and pitcher- shaped Difflugiae there seem to be two distinct sub- groups: firstly, types with thecae constructed with rather tiphtly fitted silica plates. This results in relatively smooth surfaces and contours. Their pseudopodia 
contain large crystals. This sub- group includes types $1.1 .1,1.1 .2,1.3 .1,5.2,5.3,5.4$, with a total of 58 amoebae observed in living condition. Secondly, types that build their tests with rather coarse sand of any shape, with sometimes intermittent zones of tightly fitted, smallest particles. They appear to be opportunistic in the choice of their building materials, this, at least, is the impression of the observer. Their pseudopodia do not contain larger crystals. This sub- group includes types $1.1,1.2,1.3$, (all three perhaps belonging to the same species), 2.1,2.2,3.1 and 5.1, with a total of 60 amoebae observed in living condition. In the course of analysis it was the distinction between pseudopodia with, and without, crystals that led to the recognition that the architecture of the tests, too, was different, and that, therefore, types 1.1.1, 1.2.1 and 1.3.1 are probably different species from types 1.1, 1.2 and 1.3. For these reasons I suspect that morphotype 1.5 may contain a mixture of species, as pseudopods with, and without, crystals were observed. Morphotypes 3.4 and 4.2 are alltogether different species with a very distinct architecture.

Of the 75 individuals, belonging to 20 morphotypes, which contained identifyable food particles or were actually observed to ingest food, 67 individuals belonging to 18 morphotypes ingested fungus hyphac and fungus spores. Other food particles include smallest thecamoebae (Arcellidae, Cryptodiffugiaceae and small Euglyphidae), diatoms and starch grains of an unidentified fruit; only a single obscrvation refers to a possible uptake of bacteria (type 4.1 ).

Only 36 of the total of 129 listed morphotypes were ever observed in living condition, (comments see p. 88).

\section{ACKNOWLEDGMENTS}

I am thanking Dr. A. Berkaloff of the CNRS of France for the permission to use the facilites of their "Archives du service de documentation" in Paris;

Dr. J. Cheveaugeon (ORSTOM) for the gift of a copy of Decloitre's catalogue of the the- camoebians of the world $(35 \mathrm{~mm}$ - film, will be deposited in the Collection of invertebrates, Divisão de Entomologia, INPA);

Prof. Dr. P. Vanzolini, Dr. L. Decloitre and $\mathrm{Mr}$. I. Leipnitz for important information on the subject of thecamoebae fauna;

Dr. P. Henderson and Dr. H. Schubart for critically reading the manuscript;

Miss C. Botinelly for the difficult task of typing the English script, and Mr. J. B. da Silva and Mr. J. J. Palheta for their patient and concienscous help in the field.

\section{Resumo}

A fauna das tecamebas em detritos orgânicos foi analisada em 7 igarapés da região de Manaus, entre eles o da "Bacia Modelo" (Reserva Florestal "Km 60" do (NPA). A metodologia de análise foi publicada anteriormente (Walker \& Lages 1980). Uma lista com figuras das 129 morfo-espécies caracterizadas encontrase no anexo deste trabalho, 39 espécies foram observadas em condição viva, e em 20 delas foram determinadas partículas de alimentos (75 tecamebas foram observadas). O alimento principal são fungos que decampõem a matéria orgânica na água (folhiço submerso, detritos; 67 indivíduos de 18 morfotipos foram observados inferingo fungo). A análise quantitativa mostra que a maioria das espécies de cada igarapé foi encontrada pela amostragem efetuada (64-75/igarapé) mas no caso de coletas em demals igarapés esperase um número considerável de novas espécles. A freqüência e distribuição das morfo-espécies, assim como a densidade total, é específica para cada igarapé, e parece estar ligada à qualidade química da água. A densidade total é de $360-530$ tecamebas $/ 1 \mathrm{ml}$ detritos em suspensão em águas pretas, e de $45-330 / 1 \mathrm{ml}$ em águas cristalinas. A distância geográfica, separando os igarapés, também contribui a uma redução na similaridade em morfo-especcies entre vários igarapés. Indices de diversidade (Williams' $a$ ) e de similaridade ( $\%$ morfótipos em comum) encontram-se na Tabela 2 e na Fig. 4. A distribuição das espécies freqüentes (encontradas em $\gtrless 10 \%$ das amostras] em 5 igarapés da Bacia do rio Tarumã (Fig. 1) é apresentada na Tabela 3. Todos estes resultados são suporte a hipótese de que populações integradas de tecamebas, também morfótipos especificos, podem servir como indicadores para a qualidade das águas de igarapés florestais em condição natural, e sob perturbação. Assim sendo, serão no futuro comparadas as populaçōes de tecamebas nos igarapés da "Bacia I" (Bacia Modelo) e da "Bacia III" (Bacia do Manejo Florestal) na Reserva Florestal " $\mathrm{Km} \mathrm{60"} \mathrm{do}$ do INPA. Nota-se que a riqueza de um total de 129 morfo-espécies en 7 igarapés amazônicos (drenando 
menos de $50 \mathrm{~km}^{2}$ J corresponde aproximadamente à fauna integral de tecamebas de toda Holanda (Cailleux, 1978).

\section{REFERENCES}

BONNET, L.

1979 - Thécamoebiens de quelques sols du Brésil, du Paraguay. Bull. Soc. Hist. Nat. de Toulouse, 115: 119-122.

CAILlEUX, C.

1978 - Répartition géographique des espèces de thécamoebiens. C. R. Soc. Biogéogr., 472: 29-39.

DECLOITRE, L.

1964-1976 - Travaux déposés aux archives du C.N.R.S., 15 Quai Anatole France, Paris. N. 403: Faune thécamoebienne d'Europe par pays et régions. N. 404: Faune thécamoebienne du monde. N. 404 (6): Faune thécamoebienne du monde: espèces nouvelles.

1981 - Le Genre Trinema Dujardin, 1841. Révision à jour au 31.12.1979. Arch. Protistenk. 124: 193-218.

DOCUMENTA GEIGY

1960 - Wissenschaftliche Tabellen. 6. ed. Basel..

JANZEN, D.H.

1974 - Tropical black-water rivers, animals and mast fruiting by the Dipterocarpaceae. Biotropica, 6: 69-103.

KENSLEY, B. \& 1. WALKER

1982 - Palaemonid shrimps from the Amazon basin, Brasil. (Crustacea: Decapoda: Natantia). Smithsonian Contribution to Zoology. 362: $1-28$.

KUDO, R.R.

1966 - Protozoology. 5. ed. Springfield III. In for Illinois, C. Thomas.
LEENHEER, J.A.

1980 - Origin and nature of humic substances in the waters of the Amazon river basin. Acta Amazonia, 10 (3): 513-526

LOEBLICH, A.R. \& H. TAPPAN

1978 - Thecamoebians. In: Treatise on invertebrate palentology R.C. Moore ed. v. I/C, 510p. The University of Kansas Press.

MOORE, R.C. ed.

1978 - Treatise on invertebrate paleontology. 510p.

OGDEN, C.G. \& R.H. HEDLEY

1980 - An atlas of freshwater testate amoebae. Brit. Mus. Nat. Hist., Oxford University Press. 221p.

SOUTHWOOD, T.R.E.

1979 - Ecological Methods. Methuen \& Co Ltda.

WALKER, I.

1978 - Rede de alimentação de invertebrados das águas pretas do sistema do rio Negro. 1. Observações sobre a predação de uma ameba do tipo Amoeba discoides. Acta Amazonia, 8 (3): 423-438.

WALKER, I. \& LAGES M.T.

1980 - Adaptation of constant effort sampling and of removal trapping for the estimation of populations of microscopic organisms in dense substrates. Acta Amazonica, 10 (3): 535-544.

WILLIAMS C.B.

1947 - The logarithmic series and the comparison of island floras. Proc. Linnn. Soc. London, 158: $104-108$.

(Aceito para publicação em 16/08/82) 
TABLE 2 - Results of systematic sampling series in the drainage system of Rio Tarumã and of occasional samplings in the systems of Rio Cuieiras and Rio Tarumã-Mirim. $\sum x=$ total number thecae in sample series; $\bar{x}=$ mean number per sample; $\mathbf{s}$ and $\mathbf{s}^{2}=\mathbf{s t a n d a r d}$ deviation and variance. $\mathbf{d} / \mathbf{m l}$ $=$ density, i. e. number of thecae per $\mathrm{ml}$ of settled detritus (approximate, see p. 82). Williams $\alpha=$ index of diversity (Williams 1947; Southwood 1979). Asterisks: in part pooled samples from several spots, $s$ and $\mathbf{s}^{2}$ therefore relatively small.

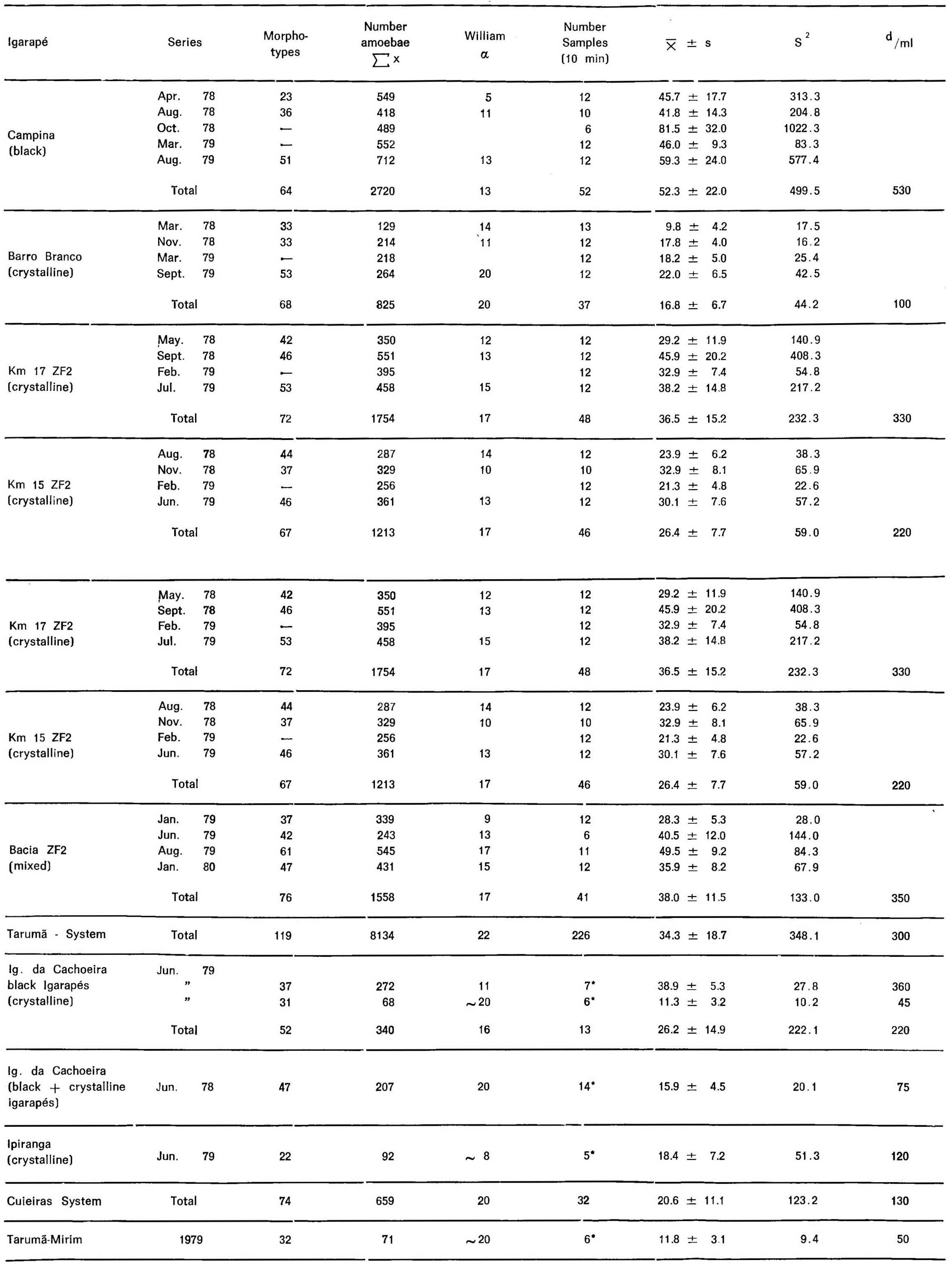

